\title{
Article
}

\section{In search of James Croll: archives, genealogy, publications and other resources}

\author{
Kevin J. EDWARDS 1,2 ๑)
}

\author{
${ }^{1}$ Departments of Geography \& Environment and Archaeology, School of Geosciences, University of Aberdeen, \\ Elphinstone Road, Aberdeen, AB24 3UF, UK. \\ ${ }^{2}$ McDonald Institute for Archaeological Research and Scott Polar Research Institute, University of Cambridge, \\ Cambridge, UK.
}

Email: kevin.edwards@abdn.ac.uk

\begin{abstract}
Source materials for investigating the life of James Croll are examined and collated. This is organised around the topics of: Croll's Autobiographical sketch and the Memoir of his life and work, both contained within the volume produced by James Campbell Irons; publications by Croll; aspects of his genealogy; manuscript sources in publicly accessible archives and in private ownership; and other published sources.
\end{abstract}

KEY WORDS: bibliography, biography, family history, source material.

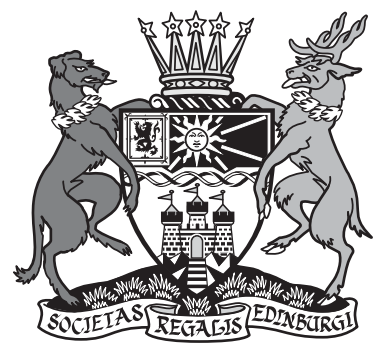

This Special Issue presents overviews of the life and work of the 19th Century climate change pioneer James Croll. The predominant emphases within the volume are based upon published material, but exceptions to this are those contributions which are informed strongly by archival sources (Brassington 2021a, b; Edwards 2021; Edwards \& Robinson 2021). This paper collates source materials for investigating the life of Croll ( $c f$. Betterton 2019a, b, c; Edwards 2021; Edwards \& Robinson 2021). This paper collates source materials for investigating the life of Croll (cf. Betterton 2019a, c) and also seeks to examine, mainly in summary form, the diverse materials which may illuminate the biography of a historical figure. The discursive element of this work is structured as follows:

- The Autobiographical sketch and Memoir

- Publications by James Croll

- Genealogy - vital, monumental and related records (wills, probate, etc.)

- Manuscript sources - archival, including related digital resources

- Manuscript sources for sale and in private ownership

- Published sources - including catalogues, thesis and digital resources

This arrangement might be considered unconventional in that it does not proceed from primary manuscript sources to secondary published ones. This is a consequence of the variety of elements under consideration and, hence, this is not a straightforwardly bibliometric study. All references are contained within section 9, which is sub-divided in terms of manuscript sources (sections 9.1 and 9.2), followed by a list of Croll's publications (section 9.3). The latter precede the list of relevant published materials that are not authored by Croll (section 9.4).

\section{The Autobiographical sketch and Memoir}

An essential starting point for those interested in a considered study of Croll is the Autobiographical sketch of James Croll LL.D., F.R.S., etc. with memoir of his life and work (Irons 1896). The substantial (553-page) compilation of commentary and correspondence, together with Croll's own Autobiographical sketch, was a labour of adulation by his solicitor friend, James Campbell Irons (1840 1910), the son of David Irons, the Perth grocer who had inducted Croll into the ways of selling tea (one of Croll's early careers).

Of great importance is the brief 33-page Autobiographical sketch and the 'Prefatory note', which Croll had dictated to his wife prior to his death (Croll 1887; Edwards 2021). The Sketch contains information on his family history, upbringing, schooling, his many jobs and homes (Edwards \& Robinson 2021), the joys and frustrations of his scientific life and the central importance to him of religion.

The Memoir has extensive portions of biographical material either copied or paraphrased from the Autobiographical sketch by Irons. In addition, there is verbatim reproduction of a large number of letters which passed between Croll and his correspondents, both scientific (e.g., Charles Darwin, Joseph Hooker, John Tyndall) and personal (and often religious - e.g., James Morison, Osmond Fisher) - for which some of the originals are to be found in the British Library (sections 4 and 9.1.3). Irons also included letters of reminiscence and obituaries by William Thomson (later Lord Kelvin) and John Horne, Croll's friend and colleague at the Geological Survey in Edinburgh (Thomson 1891; Horne 1892).

The choice of publisher for the volume - Edward Stanford of Charing Cross, London - was probably linked to the fact that Croll had published two books with them, including one completed only weeks before his death (Croll 1885b, 1890b). 


\section{Publications by James Croll}

Between 1854 and 1890, Croll published around 100 items. His publishing career was bookended by two religiously orientated philosophical volumes (Anon. [=Croll] 1857, 1890) and included a further three books (Croll 1875a, 1885b, 1889c), of which the first is the monumental Climate and time in their geological relations: a theory of secular changes of the Earth's climate. The American edition of Climate and time (with the same pagination of the main text as the British edition) was reprinted without change in 1885 by Adam and Charles Black of Edinburgh. This last company, in 1885, also produced Discussion of climate and cosmology (Croll 1885b), although the identical version published by Edwards Stanford of London is seen more commonly.

An incomplete list of Croll's publications first appeared in the obituary produced by John Horne (1892) and it was reproduced by Irons in his Memoir without specific acknowledgement. In neither case were volume or page numbers included, nor, often, were full titles and other publication details. Where possible, this information has been included in section 9.3. At the end of Horne's inventory, he said that 'The list of Dr Croll's scientific publications from 1861 to 1883 was prepared at the latter date for a special purpose. I am indebted to the kindly aid of $\mathrm{Mr}$ Bennie of the Geological Survey of Scotland for completing the list.' That 'special purpose' was presumably the memorial submitted to the 'Lords of the Committee of the Council on Education, Science and Art Department' in an effort to secure an enhanced pension (Edwards \& Robinson 2021). James Bennie (18211901) had previously worked in a paper factory and had received kindly encouragement from Croll for his fossil collecting and other geological investigations (Anon. 1901).

Croll published most frequently in the Philosophical Magazine (42 times), followed by Nature (21) and the Geological Magazine (14). The full title of the first of these was The London, Edinburgh, and Dublin, Philosophical Magazine and Journal of Science, of which Series 4 appeared in 1851-1875 and Series 5 from 1876 to 1900 . Each series consisted of 50 volumes. It has always been published by Taylor \& Francis or predecessor companies. Its appeal 'was predicated on its independence: free of the bureaucracy that attended the learned society, as well as the strictures on having to present papers before publication, Philosophical Magazine was able to present itself as a nimble operator and rapid route to publication' (Clarke \& Mussell 2015, p. 323). The current iteration of the journal, Series 8, is titled The London, Edinburgh, and Dublin, Philosophical Magazine and Journal of Science: A Journal of Theoretical Experimental and Applied Physics.

As was common during the 19th Century, a number of Croll's papers were published simultaneously in other journals. For instance, Croll (1880c), in Nature, also appeared in the Geological Magazine and the American Journal of Science and Arts. Instances of simultaneous publication are not listed as separate items in section 9.3. In some cases, the papers were split between different issues of the same journal (e.g., Croll (1865c) on glacial submergence appeared in the 2nd and 9th December issues of The Reader).

\section{Genealogy}

Croll's keen sense of family and place have been explored elsewhere (Edwards \& Robinson 2021).

The importance of his family connections was demonstrated on the first page of the Autobiographical sketch (Croll 1887), where he spoke of siblings, parents and predecessors and his consultation of the baptismal register for Cargill parish, which had enabled him to trace his (paternal) ancestors to the middle of the 17 th century. Using a combination of dispersed statements within Irons's text and genealogical data on births, marriages and deaths (e.g., accessible via FamilySearch (2021) and Ancestry (2021), including census data for the periods 1841-1901), it has been possible to construct a family tree, which extends back to approximately the first third of the 18th Century (Fig. 1). It is a little unusual for the records of this era to record so few children or to show marriages from beyond relatively local areas. Records of children who died as babies or even in infancy were not always recorded; while Croll's brief residence in Elgin as a tea merchant, and where he met his wife, was perhaps influenced by the fact that his mother's family came from that town.

The cross-matching of historical sources can, of course, be informative. An example is provided by Croll's Civil Service files associated with recruitment to the Geological Survey of Scotland. There he named John Findlay of Elgin and William Logan of Glasgow as referees (CSC 11_73-004), though without further comment other than their addresses. John Findlay was, in fact, his wife's brother-in-law (Fig. 1), and William Logan, 'much esteemed in Glasgow for the interest he took in the temperance and other social reforms' (Croll 1887, p. 27), was a director of the Safety Life Assurance Company and had offered Croll a job in 1853 as agent's assistant after the failure of his temperance hotel in Blairgowrie.

The sources for changes in names of the Croll family (Croyl $\rightarrow$ Croil $\rightarrow$ Croll), aspects of family life evident in censuses, wills and probate ('confimation') records are explored in Edwards \& Robinson (2021) and listed in section 9.1. Additional information comes from Croll's headstone in Cargill churchyard (Fig. 2). Here, Croll's father is named 'David Croll (Croyl)', whereas his surname had been 'Croil' according to his declaration of 1854 (CSC 11/73, pp. 021-23) used by James in connection with his recruitment to the Geological Survey of Scotland. Irons (1896, p. 488) talked of Croll's 'tombstone which he had been at some pains to get erected himself', yet the probable monumental mason wrote to Croll from Cargill on 25 April 1876 (Irons 1896, p. 308):

SIR,-I got the inscription that you sent me to put on the tombstone, and I send it to you as you wished to know it for the putting on of your brother's name.... If you would send me the inscription you want put on the stone as soon as convenient, I will try and get it done as soon as I possibly can, and in so doing you will oblige,--Yours truly, JOHN FENWICK.

The contents of this letter would seem to be more correct - that is, an inscription for James's brother David who died 28 February 1876. The nature of the lettering on the stone (larger size for the upper half and smaller and less spaced text in the basal portion as more names were added) would suggest that the stone was augmented rather than newly erected at James's instigation. Furthermore, the back of the stone (Fig. 2) bears the date 1787 and the initials of three individuals - Alexander Croyl, his wife Isabel Bisset, along with their son, David Croll (Croyl). The stone can surely be taken as inscribed, being by Alexander Croyl and Isabel Bisset in memory of their children who died in infancy. Alexander and Isabel would have had the stone erected as a family grave in 1787. The omission of the initials of the siblings of their son David (i.e., Mary, Christian and James) was likely because of their deaths prior to 1787, though all are mentioned on the face of the stone.

\section{Archival manuscript sources}

There are six main archival depositories relating to James Croll with regard to the numbers of documents held - the British Library, the British Geological Survey, Haslemere Educational 


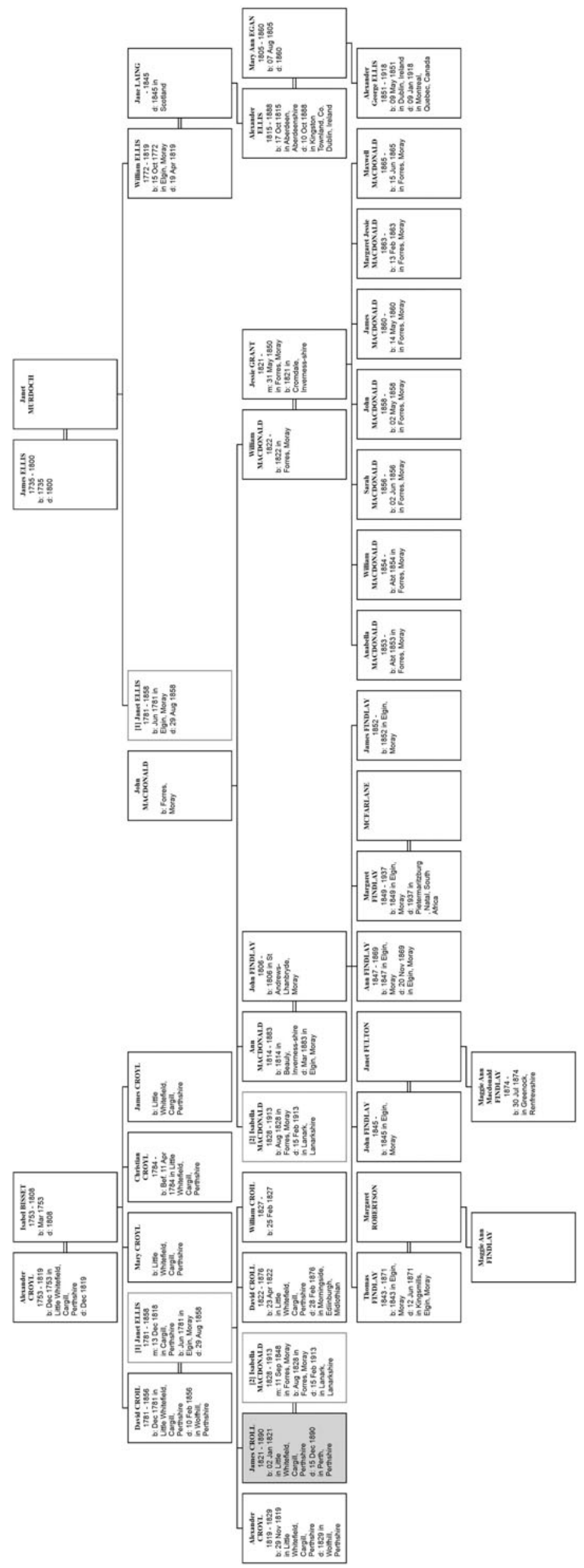

Figure 1 Extended family chart for James Croll and his wife Isabella Macdonald. James Croll's position within the chart is accentuated by shading. Note that Isabella Macdonald appears twice (middle row, left) - as James's wife and as a member of the Macdonald family - as does Janet Ellis, his mother (second row down, to left and in the centre). Abbreviations: $\mathrm{b}=$ baptismal or birth date; $\mathrm{m}=$ marriage date; $\mathrm{d}=\mathrm{death}$ or burial date. As is always the case with such records, it is important to note that it has not been possible to verify all links. 


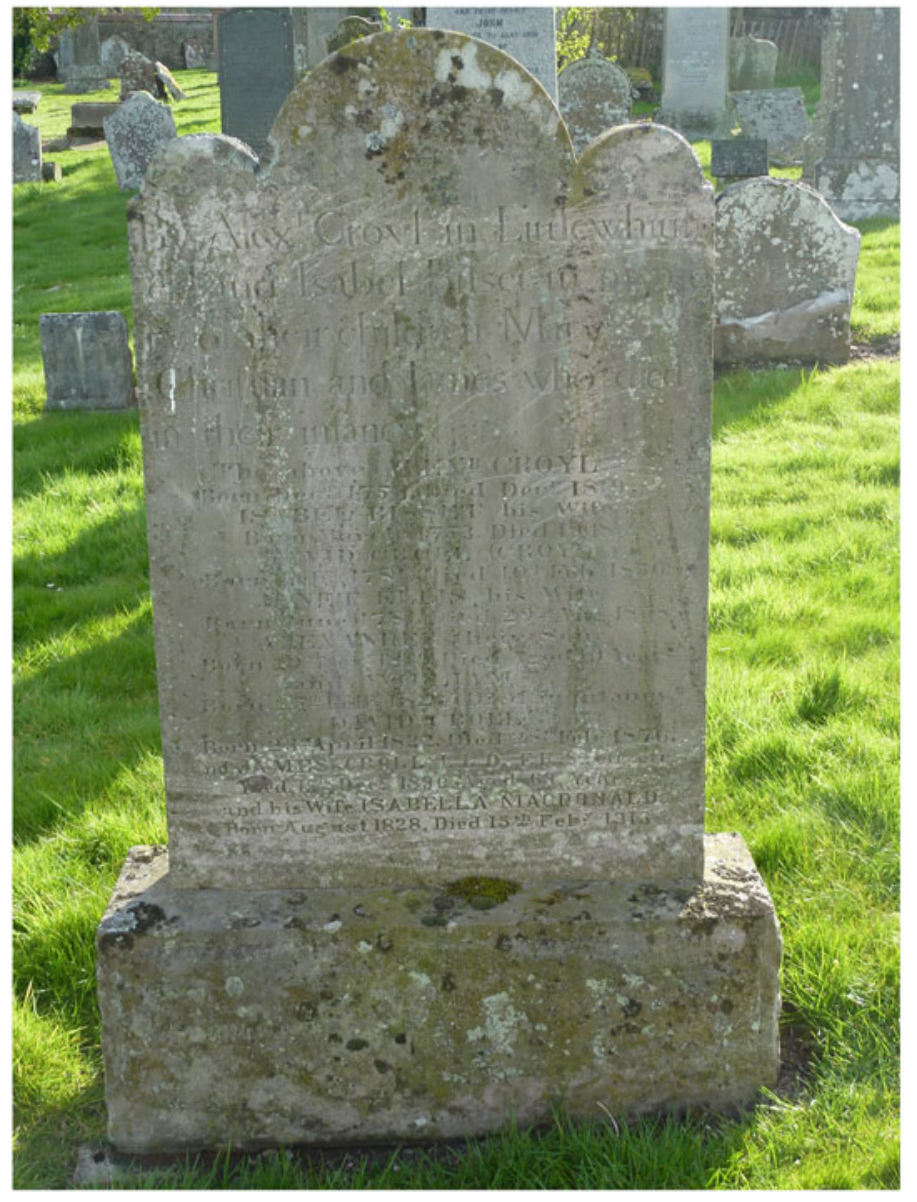

By Alex ${ }^{\mathrm{r}}$ Croyl in Littlewhitti[fi]

eld and Isabel Bisset in memo

ry of their children Mary

Christian and James who died

in their infancy

The above ALEX $^{\mathrm{R}}$ CROYL

Born Dec 1753 Died Dec 1819.

ISABEL BISSET his Wife

Born March 1753. Died 1808

DAVID CROLL (CROYL)

Born Feb 1781. Died 10 Feb 1856.

JANET ELLIS his Wife

Born June 1781. Died 29 $9^{\text {th }}$ Aug 1858

ALEXANDER their Son

Born $29^{\text {th }}$ Nov 1819 . Died aged 10 years

and WILLIAM

Born $25^{\text {th }} \mathrm{Feb}^{\mathrm{y}} 1827$. Died in infancy.

DAVID CROLL

Born $23^{\text {rd }}$ April 1822. Died $28^{\text {th }}$ Feb 1876.

and JAMES CROLL LL.D, F.R.S. etc. etc.

Died $15^{\text {th }} \operatorname{Dec}^{\text {r }} 1890$. Aged 69 years

and his Wife ISABELLA MACDONALD

Born Aug 1828, Died $15^{\text {th }}$ Feb $^{y} 1913$

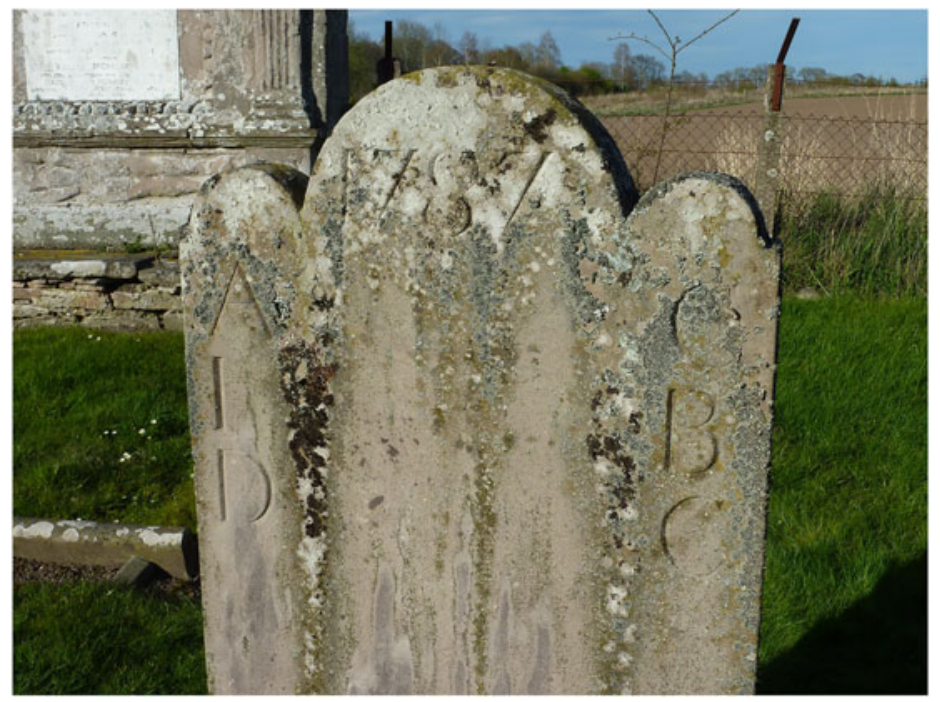

1787

$\begin{array}{ll}\text { A } & \text { C } \\ \text { I } & \text { B } \\ \text { D } & \text { C }\end{array}$

[Alexander Croyl]

[Isabel Bisset]

[David Croyl]

Figure 2 The face (top) and back (bottom) of the Croll family headstone in Cargill churchyard with transcriptions (photos: K. J. Edwards).

Museum, Edinburgh University, the University of Cambridge and The National Archives. Lesser quantities of material are in institutional and private hands. Publicly accessible material is listed in section 9.1.

The most diverse range of documents is that in the British Library collections. A number of these are clearly associated with Irons's Memoir and described as 'Letters, chiefly from men of science to James Croll...with letters to his biographer'. These represent communications from an astonishing list of notables, including Charles Darwin, Joseph Hooker, John Tyndall, Charles Lyell, Alfred Russell Wallace, Francis Galton,
Charles Wyville Thomson and Alexander Agassiz. The 'bundle' of documents was consigned under the name of Michelmore and sold as Lot 189 by Sotheby's in 1924 (Francesca Charlton-Jones, pers. comm. May 2016). The preceding lot is a collection of eight autograph letters to Charles Darwin from Croll, dated 18681875, 'on geological topics' (Sotheby, Wilkinson \& Hodge 1924). In addition, the British Library houses the papers associated with the Royal Literary Fund for writers in financial difficulties (Edwards \& Robinson 2021; RLF 2021).

The British Geological Survey archive consists of a mixture of copies of correspondence on matters such as Croll's 
appointment, medical situation and retirement, as well as a series of letters from Croll to his work colleague Benjamin Neeve Peach (1842-1926). The 28 letters to Peach span the period 1871-1884 and vary from routine work affairs to personal observations, which shed some light on Croll's persona (Edwards \& Robinson 2021).

The material on Croll within the Sir Archibald Geikie Archive of Haslemere Educational Museum covers correspondence Geikie (1835-1924) when both Director of the Geological Survey in Scotland (1867-1882) and of Great Britain (1882-1901). Copies of more than 60 letters concerning Croll (most written to him) survive for the period between 1869 and 1885 . They mainly consist of outgoing official correspondence, but also demonstrate that Geikie confided in Croll when it came to some colleagues, and that he also worked assiduously in attempting to alleviate Croll's pension and financial problems.

The Edinburgh University Library, Special Collections, has records spread across two collections. The largest group, 22 letters, sent from 1865 to 1866 to Sir Charles Lyell (1797-1875) by James Croll, are contained within Lyell's Papers (Coll-203). These are mainly of a scientific nature and cover such topics as the temperature of space, the velocity of light, the sun's heat on earth at different times of the year, orbital variations, oceanography and ice accumulation. There are also letters from Croll to Archibald Geikie (Coll-74) concerning the former's financial situation and a letter from Charles Darwin to Geikie saying that he had signed the nomination certificate of Croll for Fellowship of the Royal Society 'with real pleasure' (Coll-74; Edwards 2021).

It is possible to access 16 letters between Charles Darwin and James Croll via the Darwin Correspondence Project (University of Cambridge 2021) housed at the University of Cambridge. Some of these (as copies or originals) are to be found in archives listed in section 9.1 or reproduced in Irons (1896). In addition, the Darwin Correspondence Project also enables online searches that mention Croll in letters and publications. The transcript letters between Darwin and Croll, and dated 1868-1881, are concerned with topics such as time, denudation, alternating glaciations in the Northern and Southern Hemispheres and glacier motion. There are also 13 letters sent by Croll to Charles Darwin's astronomer son, George Howard Darwin (18451912), within the Darwin Archive of the University.

The National Archives holds documents submitted to the Civil Service Commission in association with Croll's recruitment to the Geological Survey of Scotland in 1867, with later inserts. This provides useful information on his previous employments, family issues (especially the surname change) and his examination failure. There are 28 pages of data, including some duplicate information. Most, if not all, of the material (especially the forms and a letter) is not in the hand of Croll. The aspiring geological administrator sometimes used others with neater handwriting to write on his behalf.

\section{Manuscript sources for sale or in private ownership}

A number of documents relating directly to Croll have been sold via auction houses and booksellers. These institutions are reluctant to pass on information concerning purchasers and it is difficult to determine where such material now resides. Nevertheless, it is of interest to know what is available at the time of writing, or was previously available, and some of these sales are listed in section 9.2.

This writer has also been able to obtain a small number of documents and the opportunity is taken to summarise these. These include two presentation copies of Climate and time (Croll 1875a). The first is the actual copy sent to Charles Wyville

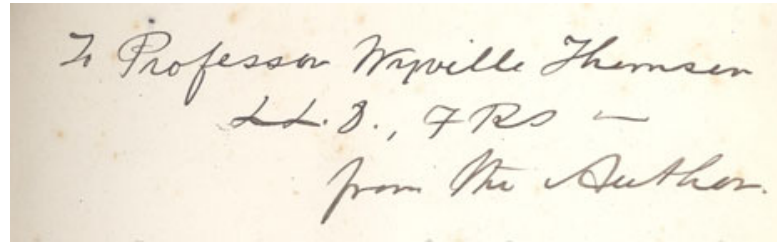

Figure 3 James Croll's inscription to Charles Wyville Thomson in a copy of Climate and time (in the writer's possession). The book was acknowledged in a letter sent to Croll by Thomson from HMS Challenger, Ascension Island, on 2 April 1876.

Thomson of the Challenger expedition. It is inscribed 'To Professor Wyville Thomson LL.D., FRS - from the Author' (Fig. 3) and was acknowledged by Thomson from Ascension Island on 2 April 1876 (British Library, Add MS 41077, ff. 86, 87; transcribed in Irons 1896, pp. 308-09). The book subsequently passed into the library of Thomson's expedition colleague and editorial successor, Sir John Murray, and bears Murray's Challenger bookplate. The second volume contains a simple inscription - 'With the author's kind regards' - and its owner was a resident of Alford, Aberdeenshire, with family farming connections in Angus.

The writer also has a collection of five offprints sent to Joseph Henry (1797-1878), Director of the Smithsonian Institute. These date from 1870 to 1879 , and one of them (Croll 1875c) is inscribed 'To Professor Henry with the author's compliments'. The offprints were accompanied by an advertising leaflet for $\mathrm{Cli}$ mate and time with the words ' $\mathrm{D}$. Appleton of New York', in Croll's hand, written beneath the printed details of the British publishers (Daldy, Isbister \& Co., 56, Ludgate Hill, London).

Collections of papers from bound volumes, reported as being owned by Croll, were available for sale in 2004 from Maggs Brothers, London, and 2017-2021 from Jeff Weber Rare Books of California, USA, and Montreux, Switzerland. Advertised as being 'From the collections of James Croll', they seem to have originated from John Turton Antiquarian Books of Crook, Co. Durham, who bought them around the year 1990 from the Hodgson's Rooms division of Sotheby's (Ben Bainbridge, pers. comm. April 2020). One of the volumes (in the writer's ownership) comprises 25 offprints with 'Pamphlets - Foreign - Vol. III' in gold lettering on the spine. The offprints are dated 1879-1880 and cover German, Scandinavian and Swiss geology and geomorphology, and they are listed (in a hand that is not that of Croll) by author and either journal or summary article title, at the start of the volume. Many of the papers are inscribed with a dedication to Croll, including those by Gottlieb Michael Berendt (1836-1920), Albrecht Penck (1858-1945) and Alfred Gabriel Nathorst (1850-1921). Not all papers have been cut, especially those by the Swiss geologist Eugène Renevier (1831-1906), which may indicate that Croll was disinterested or unwilling to read geological papers in French. This volume would appear to be a companion to another consisting of 41 offprints published in 1855-1874 on subjects such as climate, light, radiation, astronomy, climatology, glaciers and oceanography, available from Jeff Weber Rare Books. These include papers by William Thomson (Lord Kelvin; 1824-1907), William Crookes (1832-1919), Samuel Haughton (1821-1897), William Benjamin Carpenter (18131885) and George Carey Foster (1835-1919). Inscribed papers include those by Thomson, one of Croll's nominators for Fellowship of the Royal Society, and his lifelong friend Carey Foster.

Two copies of Irons's (1896) Autobiographical sketch of James Croll in the writer's possession are of particular interest. The first carries an inscription to the Dominican preacher and spiritual director, Father Arthur Henry Bertrand Wilberforce (18391904), grandson of politician and slavery abolitionist William 


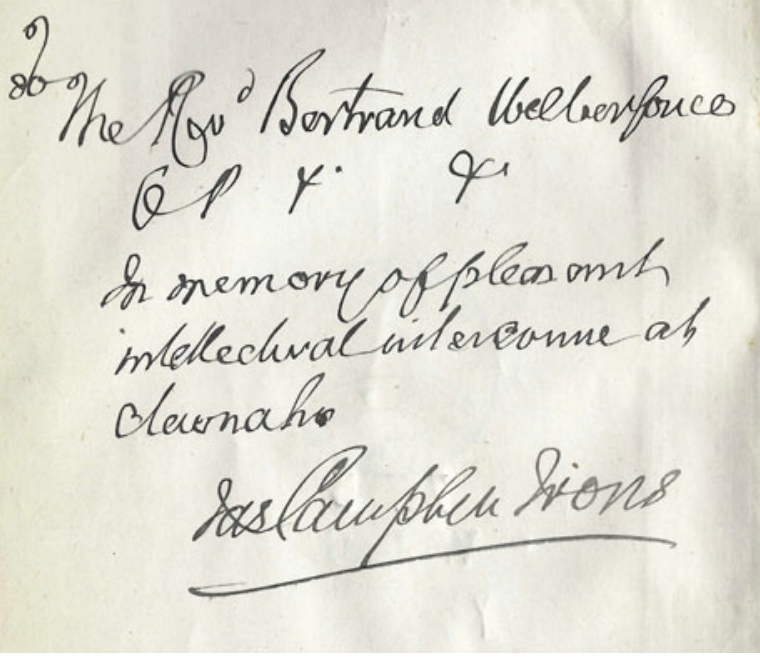

Figure 4 James Campbell Irons's inscription to Father Arthur Henry Bertrand Wilberforce in a copy of Autobiographical sketch of James Croll (in the writer's possession).

Wilberforce (1780-1825). The inscription is signed by Irons (Fig. 4) and reads 'To the Rev ${ }^{\mathrm{d}}$ Bertrand Wiberforce OP [Ordo Praedicatorum] etc. etc. In memory of pleasant intellectual intercourse at - [?]'. A bookplate for St Thomas's Priory, Hawkesyard, Rugeley in Staffordshire is pasted inside the cover. The second Irons volume contains an inscription to a Mr James G. Lunn of Paisley, with two items pasted into the front pages. The first is a handwritten excerpt from the Proceedings of the Perthshire Society of Natural Science for 1891, recording the death of 'Dr Croll, whose fame as a man of science is known to all, did honour to the Society by allowing himself to be enrolled as an honorary member.' The second is a letter from a Douglas Butter of St Martins, Burghmuir, Perth, to the eponymous Mr Lunn and dated 1 December 1946. Butter said:

I expect you will have been at Cargill Churchyard to see the stone. If you know Thomas Macqueen of Souter \& Macqueen joiners Perth, who is an elder in St Leonard's in the Fields, you could have a talk with him. He had heard Mr. Baxter talk of the famous man who belonged to Wolfhill.

The Rev. George Chalmers Baxter (1843-1908) was the Free Church minister of Cargill. The letter indicates that Croll's gravestone was clearly known locally in 1946, even if its location was subsequently 'lost' until it perhaps gained an internet presence in 2015 (Find a Grave 2021).

\section{Published sources}

There were many contemporary references to Croll's research within influential books. Thus, there is the first volume of the tenth edition of Principles of geology (Lyell 1867); the fifth edition of Origin of species (Darwin 1869); and the first edition of The Great Ice Age by James Geikie (1874). A later book was more equivocal as to Croll's contributions (Ball 1891), and various debates that related to Croll's work are to be found in the letters pages of Nature and elsewhere (e.g., Carpenter 1874a, b; F. R. S. 1874; Newcombe 1876; Somervail 1877; Watt 1890; Howorth 1892; Davis 1894; Culverwell 1896; Darwin 1896; Wallace 1896).

Soon after his death, other than obituaries (e.g., A. G. 1890; Anon. 1890; J. G. 1890; Thomson 1891; Horne 1892), there were accounts which followed the Autobiographical sketch and Memoir (e.g., Alexander 1900; Dryerre 1903), or many decades later and up to the present, hybrid biographical and research accounts of Croll in which the information on his life is clearly based upon Irons's volume (Deacon 1971; Imbrie \& Imbrie 1979; Farrow 2001; Gribbin \& Gribbin 2001; Bryson 2004).

There are also publications in the history of science which place Croll centre stage (Hamlin 1982; Tasch 1986; Kushner 2004; Fleming 2006; Bol'shakov \& Kapitsa 2010; Bol'shakov et al. 2012; Finnegan 2012) or which contextualise him within larger discussions (e.g., Zuidema 1947; Bailey 1952; Deacon 1971; Burchfield 1974, 2009; Fichman 1977; Mills 2009; Ferguson 2017; Dry 2019; Gamble 2021). At least three university theses focus upon Croll (Rothschild 2008; Brassington 2017, 2021a, b).

Croll plays a greater or lesser part in mainstream scientific literature (e.g., Fairbridge 1961; Seibold \& Berger 1982; Muller \& Macdonald 1997; Hilgen 2010; Sugden 2014; Kang et al. 2015), though this is often as a compound mention with Milutin Milankovitch or in a subsidiary role ( $c f$. Imbrie \& Imbrie 1980; Imbrie et al. 1984; Berger \& Andjelić 1988; Raymo \& Huybers 2008; Petrović \& Marković 2010; Romano et al. 2021).

Finally, papers in popularisation (Pearce 2018; Woolf 2021), a book for school children (Woolf \& Gibson 2021), blogs (Micklethwait 2004; Kneale 2019) and other online sites (Thompson 2015; Robinson 2020) can be mentioned.

\section{Concluding point}

Popular awareness of Croll is practically non-existent, while his scientific contributions are scarcely recognised by modern-day specialists other than historically aware climatologists and Quaternary scientists. It should be readily apparent from the sources presented here that the range and quantity of material which can inform the life, and particularly the work, of James Croll is considerable. The exploration of this corpus, along with the perspectives offered in this volume, have the potential to provide the bases for a sound, even innovative appraisal of a remarkable man.

\section{Acknowledgements}

The Covid-19 pandemic prevented access to a number of archives, as well as making it impossible to explore additional parish records. Nevertheless, electronic communication has enabled assistance to be received from many helpful individuals. It is a pleasure to thank the following for information, permissions and assistance: Andersonian Library, Archives and Special Collections, University of Strathclyde (Anne Cameron); British Geological Survey, Keyworth (Andrew L. Morrison); the British Library (Western Manuscripts); Edinburgh University Library, Special Collections (Daryl Green and Elise Ramsay); the Geological Society of London (Fabienne Michaud); Haslemere Educational Museum, Sir Archibald Geikie Archive (Robert Neller); Imperial College London, Records and Archives; Jeff Weber Rare Books (Jeff Weber); John Turton Antiquarian Books (Ben Bainbridge); Laura Brassington, University of Cambridge; Milton S. Eisenhower Library, Johns Hopkins University (James Stimpert); Rachel Rothschild, New York University; The National Archives, Kew (Paul Johnson); Royal Geographical Society (with IBG) (Jan C. Turner); Royal Scottish Geographical Society (Mike Robinson); Royal Society of London (Virginia Mills); Sotheby's (Francesca Charlton-Jones); Special Collections, University of St Andrews (Rachel Hart); University of Illinois at Urbana-Champaign (Adam Doskey); Wellcome Collection (Yoshika Kobayashi). The eagle-eyed observations of the referees were much appreciated. 


\section{References}

\subsection{Manuscript sources publicly available}

These represent all sources known to the writer. More are likely to come to light. The descriptions associated with these items are derived mainly from archival or online sources. The absence of dates, place of writing or further description may be an indication of restricted access. The reference notation for individual items is that used by the holding institution - for example, 'f.' and 'ff.' or 'folio(s)'; the terms have not been standardised.

\subsubsection{The Alfred Russel Wallace page.}

This website (Smith 2021) enables a search of connections such as letters, reviews and comments between Wallace and James Croll. It includes copies of the letters that are transcribed in Irons (1896).

\subsubsection{British geological survey, Keyworth, 1867-1884.}

\section{Letters from James Croll to Benjamin Peach, 1868-1884}

GSM/GL/Cr/1. 22 March 1868, Edinburgh. Concerning an accounting error.

GSM/GL/Cr/2. 28 June 1870, Edinburgh. Asks Peach to provide [Archibald] Geikie with an informal account of work completed during Geikie's absence, including details of the Leadhill fossils.

GSM/GL/Cr/3. 28 June 1870, Edinburgh. Marked private and thanks Peach for his kind wishes and favourable opinion of [Croll's] paper; annoying [head?] pain.

GSM/GL/Cr/4. 23 August 1870, Edinburgh. Enquiry from Prof. [Joseph David] Everett regarding underground temperatures; Croll's laziness for not having been to see a shell mound.

GSM/GL/Cr/5. 31 July 1871, Edinburgh. Requesting the working copy of the Berwick map sheet which should have been sent to James Geikie.

GSM/GL/Cr/6. 20 September 1871, Edinburgh. Concerning proofs of Lanark map sheets.

GSM/GL/Cr/7. 10 October 1871, Edinburgh. Discusses toothache; health; maps sent.

GSM/GL/Cr/8. 16 October 1871, Edinburgh. Dumfries and Lanark map sheets including colouration.

GSM/GL/Cr/9. 18 October 1871, Edinburgh. Request to update work record.

GSM/GL/Cr/10. 20 October 1871, Edinburgh. Marriages of [Robert] Etheridge [Jr] and [Harriman Malcolm] Skae, and related fortunes of [John] Horne and [Robert Logan] Jack; Croll glad to help Peach with office work.

GSM/GL/Cr/11. 6 November 1871, Edinburgh. Lanark map sheet.

GSM/GL/Cr/12. 9 May 1872, Edinburgh. The Director [A. Geikie] is requesting an index map colour-coded to show area surveyed by each man.

GSM/GL/Cr/13. 22 August 1872, Edinburgh. Writes of [good] quality of Peach's report; Croll 'still grumbling'; asks after the Peach family.

GSM/GL/Cr/11. 8 January 1874, Edinburgh. Fife map sheets.

GSM/GL/Cr/15. 16 March 1874, Edinburgh. Perth map sheets required by [Robert Logan] Jack.

GSM/GL/Cr/16. 19 May 1874, Edinburgh. Apology concerning map sheets.

GSM/GL/Cr/17. 21 September 1874, Edinburgh. Concerning a sketch; Croll's book nearly ready.

GSM/GL/Cr/18. 5 December 1876, Edinburgh. Peach needs to supply remuneration information immediately.
GSM/GL/Cr/19. 20 March 1878, Edinburgh. Proofs; health; stationery.

GSM/GL/Cr/20. 10 April 1878, Edinburgh. Perth map sheet proof omissions.

GSM/GL/Cr/21. 16 April 1878, Edinburgh. Stirling map sheet.

GSM/GL/Cr/22. 26 June 1879, Edinburgh. The baggage allowance for geologists; James Geikie and the glaciation of the Faroe Islands; Shetland glaciation [plus page missing]; health. Not in Croll's handwriting.

GSM/GL/Cr/23. 1 July 1879, Edinburgh. Rail receipt for luggage; Archibald Geikie and the glaciation of northern Scotland (Caithness, Moray Firth and Strathmore areas); striae; Scandinavian and North Sea ice; Orkney Islands; health. Not in Croll's handwriting as intimated in letter.

GSM/GL/Cr/24. 7 July 1879, Edinburgh. Concerning a parcel from [John] Horne for Mrs Peach.

GSM/GL/Cr/25. 13 August 1879, Edinburgh. The direction of striae in Orkney and [Archibald] Geikie's Moray ice paradox; Croll has [John] Horne's maps ready.

GSM/GL/Cr/26. 26 September 1879, Edinburgh. The coal field section has come from the engraver.

GSM/GL/Cr/27. 12 May 1884, Blairgowrie. Croll has received the Geological Magazine papers of [Henry Hoyle] Howorth. Not in Croll's handwriting.

GSM/GL/Cr/28. 18 November 1884, Hamilton. Croll asks to borrow a German Arctic expedition book to Franz Joseph Land, which details instances where islands are covered by ice sheets of their own. Not in Croll's handwriting.

\section{From entry books of in-out letters, 1867-1871}

GSM/DC/A/C/7/483, 505, 511. 13 June 1867, 3 August 1867, 15 August 1867. Referring to James Croll and his appointment as Assistant Geological Surveyor in Edinburgh.

GSM/DC/A/C/8/151, 155. 20 November 1869, 3 December 1869. Referring to promotion of James Croll to rank of Geologist.

GSM/DC/A/C/8/226. 27 January 1871. Naming James Croll as one of the employees who had not passed Civil Service examinations.

GSM/DC/A/C/8/270, 272, 277. 28 July 1871, 7 August 1871,9 September 1871. Referring to permanent appointment of James Croll.

GSM/DC/A/C/8/281-283. 23 November 1871, 8 December 1871, 16 December 1871, 22 December 1871. Concerning salary overpayments to James Croll.

\section{Correspondence to the Director General, 1876-1880}

GSM/DC/A/C/24/370. 2 October 1880, 8 October 1880, 19 October 1880. Medical certificate from Prof. Grainger Stewart concerning James Croll and associated letters, including from Andrew C. Ramsay.

\section{Correspondence to the Director General, 1881-1883}

GSM/DC/A/C/25/11, 14, 15. 10 February 1881, 22 February 1881, 24 February 1881. Medical certificate from Prof. Grainger Stewart in connection with Croll's superannuation, and associated correspondence.

GSM/DC/A/C/25/34. 9 May 1881. Letter announcing that the Treasury had awarded James Croll an annual superannuation payment of $£ 75.16 .8$.

GSM/DC/A/C/25/48, 246. 21 June 1881. Letter from Archibald Geikie to Andrew C. Ramsay suggesting appointments connected with the retirement of James Croll, viz. promoting John Horne to Geologist as 'the most efficient of the Assistant Geologists', and Robert Lunn, office porter, to become general office assistant. 
GSM/DC/A/C/25/246. 15 February 1883, 5 March 1883. Minutes, principally from Archibald Geikie, associated with the efforts of James Croll to enhance his pension, and detailing Croll's health, qualities and service.

\subsubsection{British Library, London, 1863-1865.}

\section{Add MS 41077 (in Western Manuscripts). Unless indicated otherwise, all letters are addressed to James Croll by the indivi- duals named, or this is inferred from the contents. Transcribed con- tent within Irons (1896) is indicated by '(Cf. Irons)' followed by the page number. 1863-1898}

ff. 7, 8. Early 1863 ? John Tyndall. Molecules acting as hammers. (Cf. Irons, p. 104.)

f. 9. 10 February 1864. John Tyndall. Tyndall forwarded paper (Croll 1864a) to Mr Francis without alteration. (Cf. Irons, p. 104.)

ff. 10, 11. 30 August 1864, 13 Trumpington Street, Cambridge. Rev. James Challis. [Urbain Jean Joseph] Leverrier, orbital eccentricity, Carboniferous and glacial period climates, mammoths.

f. 12. 11 November 1864, Edinburgh. George Douglas Campbell, eighth Duke of Argyll. Thanks Croll for sending publication.

f. 13. 23 February 1865, Observatory [Glasgow]. Robert Grant. [Joseph-Louis] Lagrange and calculations.

f. 14. 10 March 1865, 28 Jermyn Street, London. Sir Archibald Geikie. Thanks Croll for note and offers any geological assistance in his power.

f. 15. 13 March 1865, 59 North Vincent Street, Glasgow. William John Macquorn Rankine. Temperature of space.

ff. 16-18. 5 April 1865, Florentine Bank [Glasgow]. James Morison. Grammar, dictionary, 'by all means study French a little'.

f. 19-21. 29 April 1865. John Tyndall. Not been able to work on Croll's manuscript; heat, molecules, gravity, motion.

ff. 22, 23. 5 June 1865, Cambridge. Rev. James Challis. [Urbain Jean Joseph] Leverrier, Mars, orbital eccentricity.

f. 24. 9 June 1865, 21 Albert Road, London N.W. George Carey Foster. Temperature of rain, freezing point.

ff. 26, 27. 12 July 1865, Blackheath. James Glaisher. Temperature of rain, thermometer.

f. 28. 13 July 1865, Chilworth Manor [Surrey]. Robert Alfred Cloyne Godwin-Austen. Professor Ramsay, Journal of the geological Society.

f. 29. 19 April 1865, 5 Raglan Street, Beaumaris. Andrew Crombie Ramsay. Items in The Reader and the North Britain Quarterly, one a review of Frost and Fire by [John Francis] Campbell.

ff. 30, 31. 1865 [?]. Sir Charles Lyell. The Astronomer Royal, earth's eccentricity, coal formation, Cambrian, [William Edmond] Logan, Lower Laurentian, speculation.

f. 32. 5 May 1866, Trinity College, Dublin. Samuel Haughton. On Croll's papers in the Philosophical Magazine and The Reader, and possible misconceptions on Haughton's part.

ff. 33, 34. 19 May 1866. John Tyndall. Luminous heat from the sun reaching earth. Doubtful about conclusions of [James] Glaisher and $\mathrm{Mr}$ [James Maurice?] Wilson. (Cf. Irons, pp. 148-49.)

f. 36. 12 August 1868, 27 Inverleith Row, Edinburgh. John Hutton Balfour [nicknamed 'Woody Fibre']. Structure of wood sample in the clay.

ff. 37, 38. 26 September 1868, Rectory Welwyn. Edmund Beckett Denison, first Baron Grimthorpe. Retardation of the earth's rotation, sun's heat and Croll's apparent non-belief in the sufficiency of the meteoric theory.

f. 39. 9 November 1868. John Tyndall. Charles Darwin delighted with one of Croll's recent papers. Tyndall asks Croll if he is a Fellow of the Royal Society. ( $C f$. Irons, p. 203; Edwards 2021.)

f. 40. 19 November 1868, Geological Society, Somerset House, W. C. Alfred Tylor. Thanking Croll for some papers and saying that his own paper was not favourably received.

f. 41. 28 January 1870, Geological Survey Office, Jermyn Street, London SW. William Whitaker. Thanks Croll for paper on old river channels under drift (Croll 1870a) and offers others in return.

f. 42. 8 February 1870, Batavia. Jean Abraham Chrétien Oudemans. Oudemans had left Leiden 13 years previously, but was sending Croll requested data anyway. Inclination and axis of rotation with a diagram. Awaits a tract on geological time by Croll (one or all of Croll 1868a, 1868b, 1868c?) and being forwarded by his father in Arnhem.

ff. 46, 47. 14 March 1870, 9 St Mark's Crescent, Regent's Park, NW. Alfred Russel Wallace. Thanks Croll for the old river channels paper (Croll 1870a) and said he had made use of Croll's tables of eccentricity in Nature (Wallace 1870). Wallace claimed 'a very scanty practical acquaintance with geology'. (Cf. Irons, p. 247.)

ff. 48, 49. 15 March 1870, Dollar Institution. David Laird Adams. Asks Croll to provide a testimonial concerning an application for a Chair at the University of Otago, New Zealand. Mentions Anderson's [University] and citation in Nature of Croll's papers on eccentricity (Wallace 1870).

f. 50. 22 March 1870, 25 Devonshire Place, Portland Place. John Gwyn Jeffreys. Thanks Croll for his paper on ocean currents (cf. Croll 1870b, c) and suggests he sends a copy to Prof. [Sven Ludvig] Lovén in Stockholm. Mentions the [HMS] Porcupine expedition.

f.52. 26 March 1870, Nash Mills, Hemel Hempstead. John Evans. Thanks Croll for paper on ocean currents in relation to the distribution of heat over the globe (Croll 1870b).

f. 54. 27 April 1870, Gotha. August Heinrich Petermann. Mentions Croll's work on the Gulf Stream mentioned by Sir Andrew Waugh at a meeting of the Royal Geographical Society.

f. 55. 27 September 1870, Bonnytoun, Linlithgow, NB [North Britain]. Sir Charles Wyville Thomson. Thanks Croll for notes; Petermann; visit to Edinburgh.

ff. 56, 57. 23 December 1870, 24 St George's Road, SW. John Ball. Thanks Croll for papers and sends some in return.

ff. 58, 59. 20 October 1871, 42 Rutland Gate, London. Sir Francis Galton. Thanks Croll for memoir on ocean currents and curious to hear [William B.] Carpenter's 'answer'.

f. 60. 31 October 1871, 15 Lombard Street, EC. John Lubbock. Thanks Croll for memoir and would like to meet him if he were in London.

ff. 61, 62. 22 January 1872, Rushmere, Malone Road, Belfast. Joseph David Everett. Discusses the letter in Nature (Croll 1872a), appreciates the mention of the theory of [William] Ferrel, but said that Croll has taken it up wrong and he was publishing this in the journal (Everett 1872).

f. 63. 11 November 1872, Rectory, St Mary Woolnoth, Lombard Street, EC and 20 Gordon Square, London WC. Reverend William Josiah Irons. Thanks Croll for his paper on the determination of atomic motion (Croll 1872h); religious belief.

f. 64. 2 December 1872, Edinburgh. Rev. Robert Rainy. Thanks Croll for his clarificatory paper on molecular motion (Croll 1872h).

f. 65. 21 January 1873, 20 Mornington Road, London NW. Sir William Crookes. Thanks him for his paper on molecular motion (Croll 1872h), which has given him much pleasure, and invites Croll to contribute a related article to the Quarterly Journal of Science, though he 'does not wish to introduce religious topics into a science journal'. 
ff. 66, 67. 13 June 1873, Shoreham, near Sevenoaks. Sir Joseph Prestwich. He is about to bind several of Croll's papers but would appreciate more and can send some of his own in return.

f. 681 July 1873, 21 Eccleston Square, SW. Sir Clements Robert Markham. Thanks Croll for papers on ocean currents and would appreciate a memorandum on the importance of the currents and temperatures of the sea at different depths around the North Pole. (Cf. Irons, pp. 273-74.)

f. 70. 27 August 1873, Encyclopædia Britannica, 6 North Bridge, Edinburgh. Thomas Spencer Baynes. Invites Croll to visit to discuss assistance to the 'geological department'. ( $C f$. Irons, p. 275.)

f. 71.13 January 1874, 56 Ludgate Hill, London EC. Reverend John Cunningham Geikie. Thanks Croll for his paper on molecular motion (Croll 1872h) and implores him to come more to the 'front' ( $c f$. Edwards \& Robinson 2021). He first became aware of Croll's abilities in the book by James Geikie (1874).

f. 72. 16 January 1874. Sir Joseph Dalton Hooker. Answers a query of Croll's concerning a source - [Edward] Belcher's volume Last of the Arctic voyages.

f. 74. 16 March 1874, Bourne House, Cambridge. Isaac Todhunter. Acknowledges receipt of papers; earth's eccentricity at various epochs.

ff. 76, 77. 18 March 1874, Ely. Sydney Barber Josiah Skertchly. Thanks Croll for a recent ocean currents paper (Croll 1874b). Mentions his own research on heat, soils, vegetation and evaporation. Candid views on [William B.] Carpenter - 'he is certainly as much at sea as if he were on The Challenger....irrelevant nonsense'.

ff. 78, 79. 12 August 1874, Tunbridge Wells. Vice-Admiral Thomas Abel Brimage Spratt. Concerning Croll's views on ocean currents and those of [William B.] Carpenter; feels that Carpenter used false premises and misrepresentation.

f. 80. 26 April 1875, Stanfield House, Southsea. Admiral Sir George Strong Nares. Thanks Croll for his book (Croll 1875a) and his observations during future voyages will be at Croll's service.

f. 81. 27 December 1875, 2 Chester Street, Edinburgh. John Gray M'Kendrick. Thanks Croll for reprints.

f. 82. 11 August 1876, Christiania [Oslo]. Amund Hellard. Thanks Croll for sending publications and, in return, sends foreign language papers on the formation of fjords and lakes with more to come on ice-filled fjords of Greenland.

ff. 84, 85. 17 February 1876, The Hague. Jansen. Responds to a letter from Croll and discusses wind theory, waves, Gulf Stream, currents, ocean circulation, gravitation, Climate and time (Croll $1875 \mathrm{a}$ ) and orbital eccentricity. ( $C f$. Irons, pp. 304-05.)

ff. 86, 87. 20 April 1876, [HMS] 'Challenger', Ascension [Island]. Sir Charles Wyville Thomson. Thanks Croll for sending him a copy of Climate and time (Croll 1875a) and says that much material has been collected and a report has been sent to the Royal Society (Thomson 1876). (Cf. Irons, pp. 308-09.)

f. 88. 1876. James Hutchison Stirling. Not seen.

f. 91. 2 February 1877, 15 Royal Terrace, Edinburgh. Charles Piazzi Smyth. Asks Croll for any data on orbital eccentricity and the obliquity of the ecliptic around 4000 years ago. ( $C f$. Irons, p. 320.)

f. 93. 15 September 1877, 28 Jermyn Street, London SW. Henry William Bristow Thomson. Thanks Croll for his paper on the sun (Croll 1877) and intends to get Croll's papers bound in 'one goodly volume'. Sends Croll a picture of himself and would welcome one in return to 'add to my own gallery of British worthies'.

f. 95. 17 April 1878, 8 Crescent Road, Bromley, Kent. Sir William Matthew Flinders Petrie. Thanks Croll for sending his paper on the sun (Croll 1877).

ff. 96-101. 15 May 1879, Museum of Comparative Zoology, Harvard College, Cambridge, Massachusetts. Alexander Agassiz. Suggests to Croll that we should look for the supply of heat from the Northern Hemisphere and not so much to the Gulf Stream proper. ( $C f$. Irons, pp. 331-32.)

f. 99. 1879. Balfour Stewart. Not seen.

ff. 102, 103. 16 May 1880, Hotel Reichemont, Geneva. Edwin Paxton Hood. Generalised philosophical points.

f. 104. 18 March 1883, 31 Kensington Park Gardens. George Croom Robertson. Provides address for Mr Shadworth Hodgson and commends Croll for the imposing list of names [on the memorial related to the attempt to obtain a larger pension].

f. 106, 107. 23 March 1883, 18 Cornwall Terrace, Regent's Park, NW. George John Romanes. Comments on Croll's views on causality, determinism, force and gravity. He has just published an anonymous poem 'The more excellent way' (Anon. 1883), which he thinks may interest Croll. (Irons, pp. 402-03.)

f. 120. 17 July 1888, Savile Club, 107 Piccadilly, W. Edward Clodd. Brief mentions of [Richard Anthony] Proctor, [Joseph Norman] Lockyer and theory.

ff. 121, 122. 13 November 1888, 23 Denning Road, Hampstead, NW. Thomas George Bonney. Does not know if the Geological Society will publish Croll's paper (Croll 1889b?) in their journal given Bonney's previous dealings with the Duke of Argyll concerning Darwin's theory of corals and a paper to the Society by [Henry Brougham] Guppy; Argyll did not have the decency to apologise; 'the inexhaustible inaccuracy of his Grace's imagination'; Croll's health.

ff. 123, 124. 3 December 1888, Observatory, Co. Dublin. Sir Robert Stawell Ball. Honoured that Croll has consulted him; solar system; energy; eccentricity; heat; glacial phenomena.

f. 125. 24 January 1890, Hurstcote, Chilworth, Surrey. St George Jackson Mivart. Maintains that the evolution of organisms takes place through definite innate tendencies and directs Croll to his book, On truth (Mivart 1889).

f. 144. 21 January 1895, 21 Eccleston Square, SW. Sir Clements Robert Markham to James Campbell Irons. Regrets that he had not kept any letters from James Croll, nor did he have formal acquaintance with him.

f. 147. 3 April 1897, 'Private', 10 Downing Street, Whitehall SW1. Arthur James Balfour to James Campbell Irons. Balfour was 'glad to consider whether anything ought to be done for Mrs Croll.' (Cf. Edwards \& Robinson 2021.)

f. 150. Thursday [15 February 1867 according to Irons (1896, p. 153), but that was a Friday]. John Tyndall. Asks if there is any necessity for saying that the surface of the moon exposed to the sun's radiation is colder than the earth. ( $C f$. Irons, p. 153.)

f. 151. 17 September [1874?] John Tyndall. John Tyndall. Writes that a new edition of an address will be published this week and sent to Croll. [This is possibly Tyndall (1874).]

f. 152. Tuesday [19 February 1867 according to Irons (1896, p. 153)]. John Tyndall. Thinks that the view expressed by Croll is more in harmony with existing physics than that of $\mathrm{Mr}$. [James Maurice?] Wilson. ( $C f$. Irons, p. 153.)

f. 153. 11 February [1883?], Hillhead House, Glasgow. Joseph Parker to James Campbell Irons. Croll [it is assumed] 'has the kind of head that 'goes for' a stone-wall with splendid hope [-?-]. He as energy but wants the kind of wheedling courtesy that goes so far in spineless London.' ( $C f$. Edwards \& Robinson 2021.)

\section{Royal Literary Fund (RLF). Dr James Croll, 1885}

Loan 96 RLF 1/2220/1. 20 April 1885. Application form, James Croll.

Loan 96 RLF 1/2220/2. 6 April 1885. James Croll to Arthur Llewelyn Roberts [Secretary], asking for prospectus, sent from Burnbank Road, Hamilton.

Loan 96 RLF 1/2220/3. 20 April 1885. James Croll to Arthur Llewelyn Roberts, letter of application, sent from Burnbank Road, Hamilton, not in Croll's handwriting. 
Loan 96 RLF 1/2220/4. 13 April 1885. Sir Joseph Dalton Hooker to the Secretary of the RLF, reference for James Croll, sent from Royal Gardens, Kew.

Loan 96 RLF 1/2220/5. 16 April 1885. John Bower to the Committee of the RLF, medical certificate on behalf of James Croll, sent from Perth, NB [North Britain].

Loan 96 RLF 1/2220/6. 20 April 1885. Henry Alleyne Nicholson to the Committee of the FLF Fund, reference for James Croll.

Loan 96 RLF 1/2220/7. 21 April 1885. James Croll to Arthur Llewelyn Roberts, noting enclosure of letter from Nicholson, sent from Burnbank Road, Hamilton.

Loan 96 RLF 1/2220/8. James Croll to Arthur Llewelyn Roberts, 27 April 1885, correcting financial ambiguities in his application, sent from Burnbank Road, Hamilton, not in Croll's handwriting.

Loan 96 RLF 1/2220/9. 27 April 1885. James Croll to the Committee of the RLF, restating financial information and detail on submission of publications, sent from Burnbank Road, Hamilton, not in Croll's handwriting.

Loan 96 RLF 1/2220/10. 11 May 1885. Archibald Geikie to Secretary of the RLF, reference for James Croll, sent from 28 Jermyn Street, SW.

Loan 96 RLF 1/2220/11. 15 May 1885. James Croll to Arthur Llewelyn Roberts. Thanks RLF for the award, sent from Burnbank Road, Hamilton.

Loan 96 RLF 1/2220/12. 15 May 1885. James Croll to the Lords and Gentlemen of the Committee of the RLF, thanking them for the award of $£ 100$, sent from Burnbank Road, Hamilton.

Loan 96 RLF 1/2220/13. 15 May 1885. Receipt for the award, signed James Croll.

Loan 96 RLF 1/2220/14. April 1885. Printed list of scientific papers and works by James Croll with press opinions and handwritten additions.

\subsubsection{The Geological Society of London, 1867-1876.}

GSL/L/R/19/6. 19 February 1872. Secretary's In Letter from James Croll thanking the Society for the cheque from the Wollaston Fund.

GSL/L/R/19/180. 22 February 1876. Secretary's In Letter from James Croll thanking the Society for the cheque from the Murchison Fund.

LDGSL/789/110. 6 August 1867. Letter from Roderick Impey Murchison to Archibald Geikie concerning the work of James Croll and his theories.

LDGSL/838/G/2/20. 11 August 1867. Ardrossan. Murchison Correspondence. Letter from Archibald Geikie to Roderick Impey Murchison concerning the latter's letter of support for the appointment of James Croll to the Survey - Geikie hopes it will hold sway with his employers.

LDGSL/838/G/2/21. 19 August 1867. Ardrossan. Murchison Correspondence. Letter from Archibald Geikie to Roderick Impey Murchison saying he will be pleased to inform James Croll of the steps taken by Murchison to ensure Croll's appointment to the Survey.

LDGSL/838/G/2/41. 6 January 1870. Edinburgh. Murchison Correspondence. Letter from Archibald Geikie to Roderick Impey Murchison ruing the lack of promotion for James Croll because of the examination failure.

LDGSL/838/G/2/47. 14 April 1870. Naples. Murchison Correspondence. Letter from Archibald Geikie to Roderick Impey Murchison, hoping that the decision that geologists at the Survey no longer must pass Civil Service exams will apply retrospectively to James Croll.

LDGSL/838/G/2/52. 17 June 1870. Ramsay Lodge, Edinburgh. Murchison Correspondence. Letter from Archibald
Geikie to Roderick Impey Murchison; Geikie unwell and James Croll will bring any correspondence to Geikie which needs to be dealt with.

\subsubsection{Haslemere Educational Museum, Sir Archibald Geikie Archive.}

\section{Letters from Archibald Geikie to James Croll, 1869-1885}

LD-8-884-P25, P26.JPG. 11 November 1869, Leadhills. Relating to permit from Caledonian Railway to examine cuttings between Glasgow and Edinburgh, Carstairs and Carlisle, etc.; [Harriman Malcolm] Skae, [Benjamin Neeve] Peach. Map sheets.

LD-8-884-P311.JPG. 23 February 1870, Ferndene, Gateshead on Tyne. Acknowledging receipt of invoice [?] etc., comments on weather.

LD-8-884-P315, P316.JPG. 24 February 1870, Ferndene, Gateshead on Tyne. Letter mistake and lease.

LD-8-884-P447.JPG. 3 September 1870, Swanstonhill by Rothesay. Re-direction of letters to Ramsay Lodge [Edinburgh], pay cheque into Geikie's account.

LD-8-884-P780, P781.JPG. 11 March 1871, Ardrossan. Murray and Gibb re catalogue delay. Enquires as to Skae's workdays. Renfrew and Dumfries map sheets, [Robert Logan] Jack, [John] Horne, Skae, [Charles R.] Bone.

LD-8-884-P782, P783.JPG. Ardrossan, 14 March 1871. Dumfries, Renfrew, Lanark map sheets.

Annoyance over alleged shirking by [Harriman Malcolm] Skae and [C. R.] Campbell. Skae signing off work again. [Robert Logan] Jack, [Charles R.] Bone, [Benjamin Neeve] Peach.

LD-8-884-P786.JPG. 15 March 1871, Ardrossan. Circumstances when Croll allegedly saw [C. R.] Campbell in Morningside - 'a matter of duty'.

LD-8-884-P786, P787.JPG. 15 March 1871, Ardrossan. Letters to Croll and Geikie's brother James regarding [C. R.] Campbell's supposed presence in Edinburgh. Geikie leg problem.

LD-8-884-P790.JPG. 16 March 1871, Ardrossan. Proceedings of the Royal Society [of London].

Geikie's leg is very painful.

LD-8-884-P794, P795.JPG. Ardrossan, 17 March 1871. Says that his brother [James] mentioned that Croll believed he had seen [C. R.] Campbell in Morningside. Geikie is in no doubt that Campbell was in Edinburgh. [Harriman Malcolm] Skae is off duty again. 'These two men have given me more annoyance than the whole of the rest of the Survey three[?] times over.'

Tells Croll that he (Geikie) is 'quite unfit for fresh work'.

LD-8-884-P799.JPG. 18 March 1871, Ardrossan. Geikie's confidence is completely shaken both in [C. R.] Campbell and [Harriman Malcolm] Skae.

LD-8-884-P931.JPG. 11 June 1871, Edinburgh. Accounts, Galloway, Killin, London, [James] Bennie.

LD-8-884-P971.JPG. 27 June 1871, 20 Kensington Park Road, London W. Hopes that Croll is recovering, claim forms to [C. R.] Campbell.

LD-8-884-P971, P972.JPG. 28 June 1871, 20 Kensington Park Road, London W. Bank cheque procedure, book from Dublin.

LD-8-884-P977.JPG. [?] July 1871, 20 Kensington Park Road, London W. Map sheet, accounts, postage, travelling, [Charles R.] Bone.

LD-8-885-P39, P40.JPG. 4 October 1871, Whithorn. Accounts, writing chapters, Glacial Period, Croll's contributions, Dumfries, [James] Craik.

LD-8-885-P370.JPG. 20 May 1872, The Grapes Inn, Whithorn. Re-direction of post to Newton Stewart and Dumfries, [John] Horne, [James] Craik, [Duncan Robertson] Irvine.

LD-8-885-P375.JPG. 28 May 1872, Newton Stewart. Expenditure, post re-direction, Dumfries. 
LD-8-885-P610.JPG. 27 November 1872, Edinburgh. Croll's sick-leave, postage.

LD-8-885-P680.JPG. 13 January 1873, Geological Survey Office. [Andrew Crombie] Ramsay and Croll's leave of absence.

LD-8-885-P786, P787.JPG. 17 March 1873, Edinburgh. Asks Croll to deal with a request from Abbé François-NapoléonMarie Moigno in Paris concerning a copy of Geikie's Physical Geography primer, including arrangements for translation into French.

LD-8-885-P797.JPG. 26 March 1873, Ramsay Lodge. Croll granted three months additional leave of absence, Geikie has a sprained foot and his wife has a cold. Following letter to [Andrew Crombie] Ramsay, says that if Croll is not better after three months, then 'I fear his case will be not a very hopeful one'.

LD-8-885-P936.JPG. 4 August 1873, Port Patrick. Examining sections, returning to Newton Stewart, re-direction of post care of the Rt. Hon. Thomas Francis Kennedy of Dunure, Dalquharran, by Maybole, Irvine.

LD-8-885-P972.JPG. 21 August 1873, Dalry, Castle Douglas. Enclosures for Messrs Murray \& Gibbon [?], direct letters to Ramsay Lodge, [Robert] Etheridge [Jr].

LD-8-885-P975.JPG. 22 August 1873, Dalry by Castle Douglas. Confounded by the letter about [James] Craik, Wigton, Port Patrick, Edinburgh.

LD-8-886-P706.JPG. 29 July 1874, Kirkcudbright. Sympathising with Croll and offering assistance.

LD-8-887-P8.JPG. 7 August 1875, Ferndene, Gateshead on Tyne. Requests [Andrew Crombie] Ramsay's geological map of England and Wales posted to him at Bush Hotel, Carlisle.

Thornhill; [Harriman Malcolm] Skae.

LD-8-887-P12.JPG. 8 April 1875, Ferndene, Gateshead on Tyne. Bills, money lost from grant, Carlisle, Buccleuch Arms Hotel, Thornhill, Dumfriesshire.

LD-8-887-P30.JPG. 23 April 1875, Stonehaven. Direction of post to Brechin and Alyth.

LD-8-887-P31.JPG. 24 April 1875, Brechin. Direction of post to Perth, Alyth, Crieff.

LD-8-887-P74.JPG. 12 May 1875, Jedburgh. Send no post to Jedburgh. Edinburgh

LD-8-887-P76a.JPG. 16 May 1875. Maps, send post to Callander, allowance forms.

LD-8-887-P77.JPG. 17 May [1875]; Note [of letters sent to?] Croll 2, [John] Horne 2, 18th [May] Croll.

LD-8-887-P77.JPG. 18 May 1875, Blairgowrie. Account forms, bank payment, feu duties, letters to 'my brother' [James], [Andrew Crombie] Ramsay and [Robert Logan] Jack.

LD-8-887-P184.JPG. 16 July 1875, Inverness. Forward letter to London for Director General's [Andrew Crombie Ramsay's] signature, post direction.

LD-8-887-P187.JPG. 23 July 1875, Granton, Strathspey. First bad day, Edinburgh, Inverness.

LD-8-887-P211.JPG. Note of letters and telegrams sent on different dates (27-30 July) to [Andrew Crombie] Ramsay, [Edward] Best, Croll, [Robert Logan] Jack, [John] Horne, R. Carruthers, [James] Geikie and [Harriman Malcolm] Skae.

LD-8-887-P211, P212.JPG. 30 July 1875, Carlisle. Direction of post, London, France, [Robert] Etheridge [Jr]. [Harriman Malcolm] Skae in a bad way, he is leaving for Forfarshire [Angus]. Weather.

LD-8-887-P227.JPG. 4 September 1875, Boulogne. Sketching, place not suiting Geikie. London, [John] Horne, [Andrew Crombie] Ramsay.

LD-8-887-P249.JPG. 21 September 1875, Stonehaven. Send post to Perth (brother James's house), traumas with [Harriman Malcolm] Skae. [Robert Logan] Jack, Auchterarder.

LD-8-887-P280, P281.JPG. 13 October 1875, Stroan, Newton Stewart. Post, Irvine. Granite blocks on summits, Merrick.
LD-8-887-P627.JPG. 17 October 1876, Arbroath. Post direction, [Harriman Malcolm] Skae's house.

South Kensington, Stonehaven, Major Donnelly.

LD-8-888-P291.JPG. 5 August 1877, Marine Hotel, Nairn. Allowances, Jermyn Street.

LD-8-889-P250.JPG. 4 August 1878, Gordon Arms, Elgin. Nairn, Bennie, [James] Linn.

LD-8-891-P449.JPG. 17 August 1880, Edinburgh. Commiserates with Croll concerning ill-health.

LD-8-892-P55.JPG. 21 October 1880, Edinburgh. Croll granted four months sick leave.

LD-8-892-P376.JPG. Last page of a letter saying that Croll's pension has been granted at $£ 75.16 .8$ per annum.

LD-8-892-P376, P377.JPG. 13 May 1881, Edinburgh. On Croll's retirement allowance and the lack of generosity, wishing him 'enjoyment of the rest you have so well earned.'

LD-8-892-P417, P418, P419.JPG. 20 June 1881, Edinburgh. Geikie secures $£ 50$ grant for Croll from the Royal Society of London and tells Croll he 'must not be too sanguine' about a Civil List pension. Highlands, Elgin.

LD-8-892-P446.JPG. 22 June 1881, Edinburgh. Geikie and his brother [James] suggest to Croll that he should write to the Royal Society (Secretary, Walter White) thanking them for the $£ 50$.

LD-8-893-P15, P16.JPG. 14 July 1881, Invercauld Arms, Ballater. The memorial [for Croll's pension] has been signed by [William] Spottiswoode, Thomas H. Huxley, [John] Evans, [Norman] Lockyer, Duke of Devonshire, John Lubbock, Lyon Playfair, Grant Duff. Donald Crawford.

LD-8-893-P46.JPG. 25 July 1881, Edinburgh. The memorial has gone in, 'well signed by MPs'.

LD-8-893-P82.JPG. 15 August 1881, Edinburgh. [Edward] Best had written to Croll. Kingussie.

LD-8-893-P176, P177, P178.JPG. 12 November 1881, Edinburgh. Rumours concerning the continuation of the Survey, [Harriman Malcolm] Skae has another son, [John] Horne, [Benjamin Neeve] Peach, [William Ewart] Gladstone.

LD-8-893-P452, P453.JPG. 2[-] January 1882, Edinburgh. No news on the pension, but optimistic, Treasury, London, Gladstone.

LD-8-894-P106, P107, P108.JPG. 7 March 1882, Edinburgh. Croll sightseeing in London, Geikie and pension issues, Treasury, Royal Bounty.

LD-8-895-P21, P22.JPG. 21 June 1882, Edinburgh. Croll peripatetic, no news from the Treasury despite approaches to John Lubbock (re. [William Ewart] Gladstone) and Lyon Playfair, London.

LD-8-895-P180, P181, P182.JPG. 27 September 1882, 28 Jermyn Street, London. Sorry about the failure of the petition and does not rate the chance of a reconsideration, Dr Granger Stewart's opinion is not of much service, wishes that Croll had made more of his 'accident' when resigning his post, Perth, Colonel Donnelly.

LD-8-895-P196, P197, 198.JPG. 2 October 1882, 28 Jermyn Street, London SW. Croll mistaken to believe no special application had been made to the Director General, steps to stir up $\mathrm{Mr}$ [William Ewart] Gladstone, encloses a cheque for $£ 10$ from a friend. (Following letter, same image, sent to [John] Evans same day regarding Croll's petition, Gladstone and waking up the authorities.)

LD-8-895-P306, P307.JPG. 10 November 1882, 28 Jermyn Street, London SW. Annoyed that [William Ewart] Gladstone has 'come to so low and important a conclusion' and Geikie hopes to obtain occasional grants from the Royal Society [of London]. Lord Rosebery, Horace Seymour.

LD-8-899-P188, P189.JPG. 7 May 1885, 28 Jermyn Street, London SW. Croll's anxiety over money, Geikie will help with Royal Society and the RLF, Geikie's childrens' ailments. 
Ventnor. (Following letter, same image, to Sir Joseph Hooker sent same day and refers to Croll trying to 'get as much money together as will enable him purchase an annuity of $£ 40$ or $£ 50$ and that he has been to some extent successful.')

LD-8-899-P224, P225, P226.JPG. 28 May 1885, 28 Jermyn Street, London SW. As a steward of the RLF, Geikie was able to plead successfully for Croll. The Royal Society has cancelled your annual subscription and application made to its Scientific Relief Fund. Sir Joseph Hooker has acted 'very chivalrously on your behalf'. Huxley.

LD-8-899-P251.JPG. 2 July 1885, 28 Jermyn Street, London SW. Croll should write a letter of thanks to the 'Council' [of the Royal Society?]. France, Strathaven.

\subsubsection{Imperial College London, Records of Thomas Henry Huxley, 1882.}

Volume 121/51, box no. 121, series 20. 14 February1882, Dawlish, Devon. Letter from James Croll to T. H. Huxley explaining Croll's meaning of Determinism and asking Huxley as to an appropriate journal for publication.

12.348, box no. 12, series 1c. 15 March 1882, 12 Harrington Street, Hampstead Road, NW. Letter from James Croll to T. H. Huxley regretting that Huxley cannot recommend publication of his article.

12.349, box no. 12, series 1c. 31 March 1882, Cumbernauld, by Glasgow. Letter from James Croll to T. H. Huxley. Thinks Huxley has misunderstood the drift of his article, which purports to prove that the fundamental principle of evolution is Determinism. Not in Croll's handwriting [probably Isabella Croll].

12.351 Box Number 12 Series 1c. No date (presumably 1882 and related to the preceding three items), first part of letter missing. James Croll requests a fair hearing and offers to send Huxley the article. Says his health is improved but he has still to avoid work.

\subsubsection{Johns Hopkins University, Baltimore, 1883.}

\section{Milton S. Eisenhower Library, 1883}

MS 276. 12 May 1883. 19 North Methven Street, Perth. Letter to Henry Sidgwick from James Croll asking Sidgwick's opinion of Croll's paper on evolution (Croll 1883a). Mentions Spenserian philosophy and metaphysics. Not in Croll's handwriting.

\subsubsection{The National Archives of the UK (TNA), Kew, 1867-1871.}

CSC 11173. Civil Service Commission. CROLL, James, file 89263. Papers submitted in connection with examination and recruitment to the Geological Survey of Scotland

CSC 11/73, p. 001. File cover form indicating file closed until 1922.

CSC 11/73, p. 002. File folder with 'Not to be destroyed' label.

CSC 11/73, p. 003. File cover sheet 'Despatched 5 September 1871', with indication that 'Certificate granted Clause 7, Sept. 4th $187 \ldots$ '.

CSC 11/73, pp. 004, 005. 29 June 1867. Copy of Form A, Croll's application to become Assistant Geologist, with personal and employment details.

CSC 11/73, p. 006. 21 August 1871. Form stating various details, e.g., age, health, name change and mentioning Archibald Geikie. Foot of page says ' 51749 Cert: refused (Use of instruments \& etc.) Asst. Geologist, Scotland 28/7/67'.

CSC 11/73, pp. 007, 008, 009. 4 September 1871. A formal letter in two hands stating that James Croll is qualified for the post of Geologist with the Geological Survey of Scotland and that the examination should be dispensed with.
CSC 11/73, pp. 010, 011, 012, 013. 22 March 1897, 1 Park Row, Albert Gate. Letter to 'Lockhart' with envelope addressed to the Secretary of the Civil Service Commission, Cannon Row, Westminster, and with a copy letter reply (sent 24 March 1897) to 'Mr Porte[r]' at the end. The letter from Porter asked if it is true that the Civil Service 'plucked' [=failed/rejected] Croll 'of "glacial era" fame', as asserted in an issue of The Academy on the authority of his biographer. If this were to be false, as Porter supposed, then he wondered if it should be contradicted. Lockhart responded that he had indeed failed, but that four years later, Clause 7 having been invented, a certificate was issued for him, noting his 'European reputation'. Therefore, 'nothing can be said to The Academy'.

CSC $11 / 73$, p. 014 . 28 July 1867 . File folder with 'Not to be destroyed' label and stamp. 'Certificate refused' written at top with subjects failed stated - use of instruments, arithmetic, spelling, handwriting - along with a querying '? Over age'. Croll's alternative surnames of Croyle and Croil are also recorded.

CSC 11/73, pp. 015, 016. Sheet headed Abstract and listing items and dates (19 June 1867-31 December 1869) associated with examination, letters to Croll and opinion as to whether Croll should have obtained a certificate.

CSC 11/73, pp. 017, 018. 29 June 1867. Form A, Croll's application to become Assistant Geologist, with personal and employment details. Foot of p. 006 says '51749 Cert: refused (Use of instruments \& etc.) Asst. Geologist, Scotland 28/7/67'.

CSC $11 / 73$, p. 019. 1 July 1867. Summary statements on age, health and name change.

CSC $11 / 73$, p. 020.25 July 1867 . Summary statement on torn partial form detailing exams taken.

CSC 11/73, p. 021. An upper document abstracted from kirk records, Cargill, on 27 October 1854 and confirming birth of James Croll on 2 January 1821. A lower document, dated October 1854, from David Croll to son James explaining change of name from Croil to Croll.

CSC 11/73, pp. 022 and 023. 1 July 1867. Letter from James Croll to the Commission mentioning medical certificate, kirk records and surname change.

CSC $11 / 73$, pp. 024, 025. 1 July 1867 . Medical certificate for James Croll from Dr James Gray to the Commission.

CSC $11 / 73$, p. 026 . ?July 1867 . Handwritten sheet mentioning observations from Prof. [Andrew Crombie] Ramsay that Croll had attracted notice for the originality of his science and is considered to be an authority on geology by Sir R. M. [Roderick Murchison] and is 'self-educated'.

CSC $11 / 73$, p. 027.4 July 1867 . Sheet signed by Croll from Glasgow confirming receipt of a circular from the Civil Service Commission.

CSC 11/73, p. 028. 1 July 1867. Part of Form A confirmation signed by Croll and acknowledging Civil Service Commission requirements as to age, health and examination date.

\subsubsection{National Library of Scotland, 1869-1878.}

MS1704, f.75. 26 October 1869. Letter to Peter Guthrie Tait from James Croll concerning a new club to be started in Edinburgh. Croll declined to join at that stage. ( $C f$. Brassington 2021a, b.)

MMSID: 9922988743804341. An annotated copy of Croll's paper 'On the probable origin and age of the sun' (Croll 1877) from the collection of James Francis Campbell. The head of the front wrapper is inscribed 'From the Author'; part of an envelope addressed to Campbell is affixed to the back wrapper. Marginalia in Campbell's hand. Tipped in at the start is a letter to Campbell from Croll (dated 9 November 1877) apologising for having missed Campbell when he called into the Edinburgh office. 
MMSID: 9922989113804341. An annotated copy of Croll's paper 'Cataclysmic theories of geological climate' (Croll 1878f) from the collection of James Francis Campbell. Marginalia written by Campbell throughout.

\subsubsection{National Records of Scotland, 1890-1913.}

Statutory Death Register 387/665, CROLL, JAMES. 22 December 1890

NRS 1891, SC49/31/143, figures 87-97. 10 January 1891. Wills and testaments, Perth Sheriff Court, mutual disposition and settlement by James Croll and Mrs McDonald or Croll spouses.

NRS 1913, SC38/42/17, figures 801-802. 15 March 1913. Wills and testaments, Lanark Sheriff Court, inventory of the personal estate of Mrs Isabella Macdonald or Croll.

\subsubsection{Natural History Museum, London, 1874-1877.}

General Manuscripts MSS. BEL. 1874. Letter to Thomas Belt (1832-1878).

Autograph Letters and Collections of the General Library. 22 June 1875. Edinburgh. Letter from James Croll on behalf of Robert Etheridge Jr (1847-1920) for a post as Senior Assistant of the Lower Section, Geology Department of the British Museum, testifying to his 'natural aptitude and moral qualifications....never idle'.

Autograph Letters and Collections of the General Library. 16 August 1877. Edinburgh. Unknown recipient. Letter from Croll mentioning Climate and time (Croll 1875a) and the rate of marine denudation.

\subsubsection{Royal Botanic Gardens Kew, 1871-1887.}

\section{Joseph Dalton Hooker Correspondence, 1878-1887}

JDH/2/1/5, ff. 107-119 and JDH/2/1/9, ff.183-187. Letters from Croll to Hooker on Croll's request to sign a petition to increase his pension from the Geological Survey along with discussion about the formation of the Antarctic ice sheet (Brassington 2021a, b; $c f$. Edwards \& Robinson 2021).

JDH/2/22/1/2 f.7. 8 or 18 March 1887. The Camp, Sunningdale. Letter from Hooker to Asa Gray where he says, 'Little Brown here would be good, but he goes a leasing[?] after geological \& tellurian speculations[,] is deep in Croll \& matters he cannot understand.

\subsubsection{Royal Geographical Society (with Institute of British Geographers), 1871.}

CB6/584, Croll, James. 1871. 12 September 1871. Letter from James Croll to the Secretary of the RGS, requesting a list of Society members as he wished to send a copy of one of his papers to some of them. The rear of the single-leaf letter is marked with contemporaneous administrative notes recording receipt on the 13 September and a pencilled note: 'Oceanography. See Proc. Vol XV \& XVIII, 1st Series' (cf. Carpenter 1871, 1874c). Croll $(1870 \mathrm{~g})$ was his most recent paper on ocean currents prior to September 1871, though at the time of writing his letter, Croll would have been aware that a continuation of that paper (Croll 1871a) was to be published in the October edition of the Philosophical Magazine.

\subsubsection{The Royal Institution of Great Britain.}

RI MS JT/TYP/1/65-66. Letter from Croll to John Tyndall. The reply is held at the Wellcome Library (MS.7777/8).

\subsubsection{Royal Society of London, 1876-1897.}

In addition to the following, there are mentions of James Croll in other collections of the Royal Society, including some of the papers relating to the Sir John Frederick William Herschel (the Herschel Papers, Ref. HS) and Miscellaneous Correspondence (Ref. MC; $c f$. Brassington 2021a, b).

MS/583/31. 6 February 1865. Copy diary of John Frederick William Herschel, transcribed by Louisa Gordon (1 January31 December 1865). Mentions the letter, which is reproduced in Irons (1896, pp. 120-122) and concerns, inter alia, the paper by Croll (1864e) about which Charles Lyell had written to Herschel.

EC/1876/08. 27 January 1876. James Croll's Certificate of Election to the Royal Society.

NLB/4/997. 17 December 1890. Copy letter from Theodore E. James to Harrison \& Sons requesting them to strike James Croll's name from the List of Fellows.

NLB/4/1079. 13 January 1891. Copy letter from Herbert Rix to George Carey Foster concerning the Scientific Relief Fund payment on behalf of Isabella Croll.

CMP/6/85. 15 January 1891. Minutes of the Council. Concerning the $£ 100$ sum from the Scientific Relief Fund entrusted to Archibald Geikie for Isabella Croll.

NLB/8/737. 15 December 1893. Copy letter from Herbert Rix to Archibald Geikie reminding him to provide the promised obituary for James Croll, amongst others.

NLB/10/783. 5 February 1895. Copy letter from Herbert Rix to James Campbell Irons to say that no obituary had been published by the Royal Society, but points out the one in the Transactions of the Edinburgh Geological Society (Horne 1892).

NLB/10/811. 8 February 1895. Copy letter from Herbert Rix to James Campbell Irons to say that Irons is correct, William Thomson mentioned James Croll and his work in his anniversary address of 1891 and copies of this may be consulted in Edinburgh if Thomson is unable to supply a copy.

NLB/14/161. 14 January 1897. Copy letter from Robert William Frederick Harrison to George Carey Foster enclosing a cheque for $£ 100$ voted by the Scientific Relief Committee in aid of James Croll (this is in addition to the sum recorded for 15 January 1891, and further to the funds indicated in Table 2 of Edwards \& Robinson (2021)).

\subsubsection{University of Cambridge, 1868-1890.}

\section{Darwin Correspondence Project, letters between Charles Darwin and James Croll, 1868-1881}

DCP-LETT-6380. 19 September 1868, Down, Bromley, Kent. Charles Darwin to James Croll. Erosion; never fully realised the truth until reading Croll's papers.

DCP-LETT-6388. 23 September 1868. Edinburgh. James Croll to Charles Darwin. Concerning copies of Croll's papers.

DCP-LETT-6473. 24 November 1868. Down, Bromley, Kent, SE. Charles Darwin to James Croll. Glaciers in North America; alternating hemispheric glacial periods.

DCP-LETT-6489. 2 December 1868. Edinburgh. James Croll to Charles Darwin. Abstract of view on change of climate.

DCP-LETT-6489F. 2 December 1868. Edinburgh. James Croll to Charles Darwin. Long letter on orbital eccentricity and glacial climates.

DCP-LETT-6491. 4 December 1868. Down, Bromley, Kent, SE. Charles Darwin to James Croll. Acknowledges receipt of book containing all Croll's papers and a manuscript.

DCP-LETT-6585. 31 January 1869. Down, Bromley, Kent, SE. Charles Darwin to James Croll. Accepts warming of Southern Hemisphere during glacial period in the Northern, though 
Lyell does not. Troubled by William Thomson's calculations of age of the earth.

DCP-LETT-6599. 4 February 1869. Edinburgh. James Croll to Charles Darwin. Argues for great age of the earth before the Cambrian period. Perspectives on William Thomson and Lyell regarding age of the earth and hemispheric heating. 'Edinburgh with all its books and learning is miserably behind in scientific literature.'

DCP-LETT-6603. 6 February 1869. Down, Bromley, Kent, SE. Charles Darwin to James Croll. Pleased that Croll gives 'a little more age to the world'. Refers Croll to papers of Moseley and Clark.

DCP-LETT-6616. 15 February 1869. Edinburgh. James Croll to Charles Darwin. Croll convinced that Tyndall's view of glacier motion is incorrect.

DCP-LETT-6630. 24 February 1869. Down, Bromley, Kent, SE. Charles Darwin to James Croll. Thanks Croll for sending proofs of the glacier motion paper (Croll 1869a).

DCP-LETT-6799. 23 June 1869. Edinburgh. James Croll to Charles Darwin. Thanks Darwin for presentation copy of the Origin of Species. Supports Darwin's view that temperate plants will move up-mountain during the hemispheric glacial alternation.

DCP-LETT-7874. 19 July 1869. Down, Beckenham, Kent. Charles Darwin to James Croll. Darwin has passed Croll's name to E. L. Youmans, editor at Appleton, New York, in connection with a monograph series.

DCP-LETT-7908. 17 August 1869. Edinburgh. James Croll to Charles Darwin. Croll declined offer from Youmans to write about geological time. Croll has pain in the head. Forthcoming paper in Philosophical Magazine on Carpenter's theory of ocean currents.

DCP-LETT-11097. 9 August 1877. Down, Beckenham, Kent. Charles Darwin to James Croll. Refers to Croll's (1877) paper on the sun and appreciates the treatment of denudation.

DCP-LETT-13421. 22 October 1881. [Not online, but transcript in Irons (1896, p. 366), and sent from 43 Claremont Road, Alexandra Park, Manchester ( $c f$. Edwards \& Robinson 2021), thanking Darwin for the presentation copy of the earthworms book.]

\section{George Howard Darwin, letters from James Croll, 1886-1890}

GBR/0012/MS DAR, Darwin Archive, Correspondence and other papers of George Howard Darwin and family. At the time of writing the archive is inaccessible. Copies of some of the correspondence is, however, reproduced in Irons (1896) as indicated in the following.

GBR/0012/MS DAR 251: 3291. 22 October 1888, 5 Pitcullen Crescent, Perth.

GBR/0012/MS DAR 251: 3657.3 May 1886. 51 Barone Road, Rothesay. (This is an additional address to those listed in Table 1 of Edwards \& Robinson [2021]).

GBR/0012/MS DAR 251: 3658. 3 November 1886. 5 Pitcullen Crescent, Perth.

GBR/0012/MS DAR 251:3659. 9 November 1886. 5 Pitcullen Crescent, Perth.

GBR/0012/MS DAR 251:3660. 5 November 1888. 5 Pitcullen Crescent, Perth. Croll responded to a letter sent by George Darwin (probably that of 24 October 1888; Irons 1896, p. 452) and discussed comets, celestial mechanics, Jupiter and Laplace (Irons 1896, pp. 452-53).

GBR/0012/MS DAR 251: 3661. 12 November 1888. 5 Pitcullen Crescent, Perth. Croll responded to a letter sent by George Darwin (probably that of 8 November 1888; Irons 1896, p. 453) where Darwin suggested that Croll's ideas of solar system energy are incorrect. Croll responded (Irons 1896, pp. 453-54) that he gathered the principle to be correct but it had been 'incautiously expressed'.

GBR/0012/MS DAR 251:3662. 15 November 1888. 5 Pitcullen Crescent, Perth. Croll responded to a postcard sent by George
Darwin (13 November 1888; Irons 1896, p. 454), which mentioned impact, Laplace and the fact that Croll was probably incorrect. Croll thanked Darwin (Irons 1896, p. 455), confessed 'I see I am still wrong', asked him to 'kindly tell me in ordinary language how this is effected' and confessed 'I never like to commit myself to an opinion before making sure that I am right'.

GBR/0012/MS DAR 251:3663. 26 November 1888. 5 Pitcullen Crescent, Perth. Croll responded to a letter sent by George Darwin (17 November 1888; Irons 1896, pp. 455-56). Darwin displayed some impatience with Croll ('After giving you the following quotation, I must leave you to look up the originals.... I have not read Laplace's or Leverrier's investigations, and it would take me too long to do so now'), but he nevertheless went into some detail concerning comets, Jupiter, Saturn and Leverrier. Croll's response was courteous but persistent (Irons 1896, p. 457) - 'I am sorry that my difficulty still remains....one that lies within very narrow bounds' - and dealt with issues of gravity, planets and the eccentricity of an object's trajectory.

GBR/0012/MS DAR 251: 3664. 24 December 1888. 5 Pitcullen Crescent, Perth. Croll began an apologetic response to George Darwin (Irons 1896, p. 457) - 'I fear you will be beginning to regard me as a bore' - before returning to the kernel of his problem: 'I am now ready for the press, and if you could give me a hint as to how a body can pass from planet to planet and get its motion accelerated by each and retarded by none, it would be esteemed a special favour'. The item for the press was the book Stellar evolution and its relations to geological time (Croll 1889c).

GBR/0012/MS DAR 251: 3665. 27 December 1888. 5 Pitcullen Crescent, Perth. Croll thanked George Darwin for allowing him to see a letter from 'Sir William [Thomson?]' (Irons 1896, p. 458).

GBR/0012/MS DAR 251: 3666. 31 December 1888. 5 Pitcullen Crescent, Perth. Croll said to George Darwin (Irons 1896, p. 458) that 'I have just come upon a most extraordinary statement of Sir William Thomson. There is surely some mistake. Would you kindly look at the page of MS. which I enclose, and give me your opinion'.

GBR/0012/MS DAR 251: 3667. 3 January 1889. 5 Pitcullen Crescent, Perth.

GBR/0012/MS DAR 251: 3668. No date or place. Concerning orbits of comets. Annotated by Margaret Keynes (née Darwin) 'Croll Perth correspondence mostly about a paper he wished to publish' - this was presumably referring to Croll (1889a, b, c).

\section{St John's College Library Special Collections, 1884}

Letters to John Couch Adams from James Croll concerning a paper in the Philosophical Magazine.

GB 275 Adams/Box 5-15/Box 6/32/2. 8 March 1884. Sends proof of paper to Adams for the Philosophical Magazine, asking Adams to give permission for information he provided to be used.

GB 275 Adams/Box 5-15/Box 6/32/1. 18 March 1884. Croll requests proof of paper to be returned.

GB 275 Adams/Box 5-15/Box 6/32/3. 20 March 1884. Croll thanks Adams for corrections to the paper for the Philosophical Magazine.

\subsubsection{University of Edinburgh.}

Edinburgh University Library Special Collections, Coll-203, Papers of Sir Charles Lyell, Letters to Sir Charles Lyell from James Croll, 1865-1866

Coll-203/1 folio(s) 580-581. 1 March 1865 . The velocity of light and effects on the temperature of the earth during the glacial period. Mentions the theories of Foucault, Le Verrier and Lagrange.

Coll-203/1 folio(s) 582-583. 6 April 1865. Croll sending an abstract of a paper containing conclusions further to a paper 
which was published in August 1863, pointing out the correspondence between geological climate and change in the earth's orbit.

Coll-203/1 folio(s) 584. 8 April 1865. Calculations and speculation concerning the temperature of space which ranges from -315 to $-224^{\circ} \mathrm{F}$.

Coll-203/1 folio(s) 585. 18 May 1865. Refers to works by Duperry, Nichol and A. Keitz Johnston and discusses superior and subordinate maxima. Asks Lyell to pass on any information he receives from the Astronomer Royal.

Coll-203/1 folio(s) 586-587. 6 November 1865 . The temperature of Iceland in the glacial epoch and at the time this letter was written, and how it is affected by season, position of the island and the presence of the Gulf Stream.

Coll-203/1 folio(s) 588-589. 25 December 1865. The eccentricity of the earth's orbit, which Croll has calculated for a million years past, and to come, at 5000 year intervals. He states that his results are favourable to the cosmical theory and will be published in the Philosophical Magazine (Croll 1866a).

Coll-203/1 folio(s) 590-592. 4 January 1866 . The build-up of ice during the glacial epoch, the level of the ocean, and his belief that the level of the ocean would not be lowered by the accumulation of ice, as the level of the water would adjust itself to the altered centre of gravity of the earth.

Coll-203/1 folio(s) 593-594. 6 January 1866. Modifications Croll has made to his submergence theory, which held that the level of the ocean would not be lowered by the accumulation of ice, arising from Lyell passing on some calculations as to the amount of water needed from the oceans to form an ice sheet of sufficient mass to alter the earth's centre of gravity. He encloses a letter to The Reader (Croll 1866b), putting the matter straight and asks for Lyell's approval.

Coll-203/1 folio(s) 595. 8 January 1866. Another alteration to his submergence theory, involving the structure of ice caps that have a solid crust covering and a liquid nucleus, which he asks Lyell to send to The Reader (Croll 1866c) with his earlier letter.

Coll-203/1 folio(s) 596-598. 12 January 1866 . The rigidity of the earth's crust and the submergence theory, enclosing a copy of his article on the excentricity of the earth's orbit (Croll 1866a).

Coll-203/1 folio(s) 599-602. 16 January 1866. Apologising to Lyell for inadvertently misrepresenting Lyell's view of the submergence theory causing him to write a letter of explanation to The Reader. Points out why he thinks Lyell is mistaken in his objections to the theory.

Coll-203/1 folio(s) 603-604. 8 February 1866 . The effect of ice caps upon the level of the ocean and announcing the publication of an important paper by the Rev. Osmond Fisher on the subject (cf. Fisher 1866).

Coll-203/1 folio(s) 605. 16 February 1866 . The extent to which the centre of gravity of the earth would be displaced by ice caps 2000 feet and 3000 feet thick.

Coll-203/1 folio(s) 606-607. 17 February 1866. Calculations of Charles Moore's, which Lyell had sent to him, and discussing his own calculations, which show how much the centre of gravity of the earth would have been displaced by the weight of ice caps.

Coll-203/1 folio(s) 608-609. 28 February 1866. Calculations made by himself and Charles Moore as to the shift in the centre of gravity due to ice caps, solstitial points and perihelion in the earth's orbit.

Coll-203/1 folio(s) 610. 6 March 1866. Concerning the view of 'the most eminent physicist that Scotland Possesses', Lord Kelvin, that a paper by $\mathrm{Mr}$ [Douglas] Heath is full of glaring errors and that Croll expects the Philosophical Magazine to have something further on the subject.

Coll-203/1 folio(s) 611-612.17 April 1866. The quantity of heat received from the sun between two equinoxes, the effect of Perihelion and Aphelion on the length and strength of summers and winters and the effect of the formation of ice and snow on the levels of heat given off from the earth.

Coll-203/1 folio(s) 613-614. 24 April 1866. The temperature of space in relation to the position of the earth and the sun, and different methods of calculating the rate at which the temperature decreases and increases depending on the amount of heat received from the sun.

Coll-203/1 folio(s) 615-618.23 April 1866. The temperature of the earth in both winter and summer and how this is affected by the position of the earth in relation to the sun, snow and ice.

Coll-203/1 folio(s) 619. 29 June 1866. Telling Lyell that he does not have anything ready to print in the July issue of the Philosophical Magazine.

Coll-203/1 folio(s) 620-621. 6 July 1866. Calculations of the thickness of the ice sheets and the extent of the submergence, the effect on the climate of the ice sheet, and his belief that the grinding down of rock cannot be attributed to floating ice but to the extent of time that the rock was covered in ice. He feels confident that the submergence and emergence both of the glacial and coal periods can be accounted for on cosmical principles.

Coll-203/1 folio(s) 622-623. 9 July 1866. (No information.)

\section{Edinburgh University Library Special Collections, Coll-74, Letter} from Charles Robert Darwin to Archibald Geikie, 1875

Coll-74/11/12. 9 December 1875. Down, Beckenham, Kent, Railway Station, Orpington. SER [South Eastern Railway]. Darwin wrote to Geikie to say he had signed Croll's nomination paper for Fellowship of the Royal Society of London 'with real pleasure'.

Edinburgh University Library Special Collections, Coll-74, Correspondence to Sir Archibald Geikie

Coll-74/11/10. 'A number [of letters] from James Croll concerning his financial situation'.

\subsubsection{University of Exeter.}

Special Collections Archives, GB 0029, Autograph letter collection of John Marshall, 1886

EUL MS 31a/422. 19 April 1886. Croll expresses interest in Marshall's recent paper on 'mind-stuff' and theism read before the Aristotelian Society.

\subsubsection{University of Glasgow.}

Archives and Special Collections, Manuscripts, GB 247, 1871

GB 247 MS Kelvin C38. 16 October 1871, Geological Survey Office, Edinburgh. Letter to William Thomson from James Croll concerning ocean currents and William Benjamin Carpenter's theory.

\subsubsection{University of Illinois at Urbana-Champaign, 1884.}

\section{Rare Book and Manuscript Library}

Three period copies of letters dated 28 March, 1 April, 6 April 1884, sent by Joseph Dalton Hooker to James Croll and copied onto blind-stamped paper bearing the address of Montreal Cottage, Perth. This was the address of Croll's friend Dr John Bower, a retired fleet-surgeon and the copyist. The letters are transcribed in Irons (1896, pp. 423-28) from originals sent from Kew by Hooker. They discuss issues of Arctic interest including the 'hopelessly unintelligible' question of whether specimens of wood found in the Arctic are evidence of interglacial warming periods, expressing scepticism as to Sir Edward Belcher's claims to have found a tree stump embedded in frozen clay. 


\subsubsection{University of St Andrews, 1865-1876.}

University Library Special Collections, Papers of James David Forbes, 1865

msdep7/Incoming Letters 1865/46 (a,b). 26 May 1865, London. Letter from Andrew Crombie Ramsay of the Geological Survey to James David Forbes, Principal of the United College, University of St Andrews, describing James Croll as a 'singularly modest man, and I suspect is almost quite self-educated.' A transcript may be found in Edwards (2021, supplementary material 1).

\section{University of St Andrews, University Library Special Collections,} Minutes of Senatus, 1873-1876

UYUY452/19, pp. 210, 213, 232, 233, 265, 266, 277, 383, 389. Minutes concerning the offer and award of the honorary degree of LLD to Croll (Edwards 2021).

\subsubsection{University of Strathclyde, Glasgow, 1860- 1920.}

\section{Archives and Special Collections}

OB/1/1/4, p. 446. 1 February 1860. Minutes of the managers and trustees of Anderson's University, 1830-1864. References to Croll's appointment as janitor, including transcriptions of Croll's letter of appointment and letter of acceptance.

OB/1/1/5. 13 September 1867. Minutes of the managers and trustees of Anderson's University/Anderson's College, 18641881 (the change of name from Anderson's University to Anderson's College occurred in 1877). Records Croll's resignation 'in consequence of his appointment to an office under the Government Geological Survey'.

OM/158/1, pp. 5-7. 25 August 1920. Copy of A. Humboldt Sexton (1894), with eight attached pages of handwritten comments by Robert Rattray Tatlock about former members of staff, including James Croll.

\subsubsection{Wellcome Collection.}

MS.7777/8. A letter from John Tyndall to James Croll held at the Wellcome Library. Tyndall mentions negative fluorescence (calorescence), mechanics, molecules and motion. He asks if Croll wishes his note to be sent to the Philosophical Magazine. This is a reply to a letter from Croll to Tyndall held at the Royal Institution (RI MS JT/TYP/1/65-66).

\subsection{Manuscript sources for sale or in private hands}

The items below should be read in combination with the details discussed in section 5 .

\subsubsection{Christie's, London.}

\section{Letters from Sir Joseph Dalton Hooker to James Croll, 1883-1884}

Christies's auction house had two related sales of Croll-related material on 17 September 1999 (Lot 163; estimate £150-£250, price realised £55) and 9 October 2012 (Lot 83; estimate $£ 1000-£ 1500$, price realised £125). The first consisted of five autograph letters from Hooker, Kew Gardens, to James Croll on Arctic and Antarctic topics, with comments on Sir Edward Belcher: 'Belcher you know was a notoriously untruthful man...the best (and most deservedly) hated man of his day in the Navy'. They consisted of 23 pages and were dated 25 November 1883-6 April 1884. A letter of 6 April 1884 lacked the second bifolium and another dated 23 December 1883 is also recorded, while the sale was accompanied by a photograph from a letter dated 28 March 1884. They were sold together with contemporary copies (including a complete text of the letter of 6 April 1884). Quotations from the letters, along with the photograph, indicate these to include those transcribed in Irons (1896), viz. 25 November 1883 (Irons 1896, pp. 407-10), 23 December 1883 (Irons 1896, pp. 418-19) and 28 March 1884 (Irons 1896, pp. 423-24). The contemporary letters almost certainly refer to those of 28 March, 1 April, 6 April 1884, sent by Hooker to Croll and copied onto blind-stamped paper bearing the address of Montreal Cottage, Perth (see under University of Illinois, section 9.1.20).

The 9 October 2012 (Lot 83) sale would seem to be the same material as for the 17 September 1999 sale, with the addition of a signed portrait of Hooker. It seems that the three copy letters on Montreal Cottage notepaper were acquired by the Wayfarer's Bookshop, British Columbia, Canada, whence they made their way to the University of Illinois in 2015.

\section{Presentation copy of Alfred Russell Wallace volume to James Croll with notes, 1880}

A first edition presentation copy to James Croll of Island life (Wallace 1880) sold as Lot 408 on 11 September 1992 by Christie's in London (price realised £55). The book contained a tipped-in slip inscribed 'From the Author', and extensive notes in the margins of chapters VII-X. The manuscript notes were possibly used by Croll in the revision of his own work (presumably Croll 1885b).

\subsubsection{Croll's paper on ocean currents, 1874 .}

An offprint of Croll's (1874a) paper and signed 'With the author's compliments' was available on the eBay platform in July 2021 and offered for sale by Robin Rare Books Division of the Midtown Scholar Bookstore, Harrisburg, Pennsylvania. The word 'Edinburgh' is also added beneath the printed address of the article's title page.

\subsubsection{Bound papers, $1855-1874$.}

A collection of 41 offprints sent to Croll and on sale at the time of writing by Jeff Weber Rare Books, Montreux. The listed contents at the start of the bound volume are not in the hand of Croll (Jeff Weber, pers. comm. April 2021).

\subsubsection{Disbound papers, $1865-1885$.}

A website detailing 19 items 'from the library of James Croll' is currently available from John Turton Antiquarian Books of Crook, Co. Durham (Turton 2021). This part of a collection of offprints bought by Turton's around the year 1990 from the Hodgson's Rooms division of Sotheby's (Ben Bainbridge, pers. comm. April 2020; $c f$. sections 5, 9.2.3. and 9.2.5.).

\subsubsection{Material currently in the possession of Kevin J. Edwards.}

Offprints, 1870-1879

A collection of five offprints (Croll 1870b, 1875c, d, e, 1879c), sent to Joseph Henry (1797-1878), Director of the Smithsonian Institute and obtained from Ed Rogers Rare and Out of Print Geology Book, Poncha Springs, Colorado. One of them (Croll 1875c) is inscribed 'To Professor Henry with the author's compliments' and is in the hand of Croll. Another with the words 'With the Author's compliments' (Croll 1879c) is not. The sale came with an advertising leaflet for Climate and time with the words 'D. Appleton of New York', in Croll's hand, written beneath the printed details of the British publishers (section 5). In 
addition, there is an offprint (Woodward 1873) sent to Croll and bearing the inscription ' $\mathrm{J}$. Croll Esq' ${ }^{\text {re }}$. Henry Bolingbroke Woodward (1832-1921) was keeper of geology at the British Museum and a signatory to Croll's nomination for the Royal Society of London (Edwards 2021). This is probably not in the hand of Croll. The offprint came from Croll's collection and was obtained from John Turton Antiquarian Books of Crook, Co. Durham.

\section{Copies of Climate and time, 1875}

The copy of Climate and time (Croll 1875a) sent to Charles Wyville Thomson of the Challenger expedition, inscribed 'To Professor Wyville Thomson LL.D., FRS - from the Author' (see section 5; Fig. 3) and acknowledged by Thomson from Ascension Island on 2 April 1876 (section 9.1.3, ff. 86, 87; Irons 1896, pp. 308-09). The book subsequently passed into the library of Thomson colleague, John Murray, and bears his bookplate. A second copy contains the inscription 'With the author's kind regards', and its owner came from Alford, Aberdeenshire, Scotland.

\section{Bound papers, 1879-1880}

A collection of papers sent to Croll and comprising 25 offprints with 'Pamphlets - Foreign - Vol. III' in gold lettering on the spine (section 5). The papers are listed by author, and either journal or summary article title, at the start of the volume in a hand which is not that of Croll. The volume would appear to be a companion to that described in section 9.2.3.

\section{Copies of Autobiographical sketch of James Croll, 1896}

One copy of James Campbell Irons (1896) contains an inscription to a Mr James G. Lunn of Paisley, with two items pasted into the front pages concerning Croll as a scientist and the location of his grave. A second copy is inscribed by Irons to the Dominican preacher, Father Arthur Henry Bertrand Wilberforce, grandson of politician and slavery abolitionist William Wilberforce (Fig. 4). More information on both volumes may be found in section 5 .

\subsection{Publications by James Croll}

Anon. [or a 'moderate Calvinist'] 1854. Predestination. [A pamphlet; Irons 1896, pp. 83, 492.].

Anon. [?] 1854. 'On the bearings of geology and astronomy on the creation of the world.' [A pamphlet; Irons 1896, ibid., p. 83].

Anon. [=Croll, J.] 1857. The philosophy of theism: an inquiry into the dependence of theism on metaphysics and the only possible way of arriving at a proof of the existence of God. London: Ward \& Co; Glasgow: J. \& D. Croll.

Croll, J. 1861. XXXVIII. Remarks on Ampère's experiment on the repulsion of a rectilinear electrical current on itself. The London, Edinburgh, and Dublin Philosophical Magazine and Journal of Science, Series 4 21, 247-50.

Croll, J. 1862a. On chemical combination in relation to specific heat Read before the Chemical Society, March 6, 1862. Chemical News, March 8, 1862.

Croll, J. 1862b. LII. Remarks on Ampère's experiment on the repulsion of a rectilinear electrical current on itself: to the editors of the philosophical magazine and journal. The London. Edinburgh, and Dublin Philosophical Magazine and Journal of Science, Series 4 23, 365-67.

Croll, J. 1862c. On the cohesion of gases, and its relations to Carnot's function and to recent experiments on the thermal effects of elastic fluids in motion. British Association Report, 1862, part II, 21.

Croll, J. 1862d. On the mechanical power of electro-magnetism. British Association Report, 1862, part II, 24.

Croll, J. 1862e. Ampèrian repulsion. The London, Edinburgh, and Dublin Philosophical Magazine and Journal of Science, Series 4 24, 326.

Croll, J. 1863. On the relation of chemical affinity to vital force. Chemical News, May 16, 1863.

Croll, J. 1864a. XXXV. On supposed objections to the dynamical theory of heat. The London, Edinburgh, and Dublin, Philosophical Magazine and Journal of Science, Series 4 27, 196-98.

Croll, J. 1864b. XLIX. On the influence of the tidal wave on the earth's rotation, and on the acceleration of the moon's mean motion. The
London, Edinburgh, and Dublin, Philosophical Magazine and Journal of Science, Series 4 27, 285-93.

Croll, J. 1864c. LV. On the nature of heat vibrations. The London, Edinburgh, and Dublin, Philosophical Magazine and Journal of Science, Series 4 27, 346- 47.

Croll, J. 1864d. LXI. On the cause of the cooling effects produced on solids by tension. The London, Edinburgh, and Dublin, Philosophical Magazine and Journal of Science, Series 4 27, 380-82.

Croll, J. 1864e. XIII. On the physical cause of the change of climate during geological epochs. The London, Edinburgh, and Dublin Philosophical Magazine and Journal of Science, Series 4 28, 21-137.

Croll, J. 1865a. On the physical cause of the submergence of the land during the glacial epoch. The Reader 2 September, 6, 270-71.

Croll, J. 1865b. On the submergence of the land. The Reader October 14, 6, 435-36.

Croll, J. 1865c. On the glacial submergence. The Reader December 2, 6, 630-31; December 9, 6, 659 .

Croll, J. 1866a. III. On the eccentricity of the Earth's orbit. The London, Edinburgh, and Dublin, Philosophical Magazine and Journal of Science, Series 4 31, 26-28.

Croll, J. 1866b. Glacial submergence on the supposition that the interior of the globe is in a fluid condition. The Reader, January 13.

Croll, J. 1866c. Glacial Submergence. The Reader, March 3 and 26, 1866.

Croll, J. 1866d. XLV. On the physical cause of the submergence and emergence of the land during the glacial epoch. The London, Edinburgh, and Dublin, Philosophical Magazine and Journal of Science, Series 4 31, 301-06.

Croll, J. 1866e. XIII. On the influence of the tidal wave on the motion of the Moon. The London, Edinburgh, and Dublin, Philosophical Magazine and Journal of Science, Series 4 32, 107-11.

Croll, J. 1866f. On the reason why the change of climate in Canada since the glacial epoch has been less complete than in Scotland. Transactions of the Geological Society of Glasgow 2, 138-41.

Croll, J. 1867a. XVIII. On the excentricity of the Earth's orbit and its relations to the glacial epoch. The London, Edinburgh, and Dublin Philosophical Magazine and Journal of Science, Series 4 33, 1-13.

Croll, J. 1867b. XXVIII. On the reason why the difference of reading between a thermometer exposed to direct sunshine and one shaded diminishes as we ascend in the atmosphere. The London, Edinburgh, and Dublin Philosophical Magazine and Journal of Science, Series 4 33, 213-16.

Croll, J. 1867c. LV. On the change in obliquity of the ecliptic; its influence on the climate of the polar regions and level of the sea. Transactions of the Geological Society of Glasgow 2, 177-98.

Croll, J. 1867d. XV. Remarks on the change in the obliquity of the ecliptic and its influence on climate. The London, Edinburgh, and Dublin Philosophical Magazine and Journal of Science, Series 4 34, 127-28.

Croll, J. 1867e. LIX. On certain hypothetical elements in the theory of gravitation, and generally received conceptions regarding the constitution of matter. The London, Edinburgh, and Dublin, Philosophical Magazine and Journal of Science, Series 4 34, 449-60.

Croll, J. 1868a. XLIII. On geological time, and the probable date of the glacial and the Upper Miocene period. The London, Edinburgh, and Dublin Philosophical Magazine and Journal of Science, Series $4 \mathbf{3 5}$, $363-84$.

Croll, J. 1868b. XIX. On geological time, and the probable date of the glacial and the Upper Miocene period. The London, Edinburgh, and Dublin Philosophical Magazine and Journal of Science, Series 4 36, 141-54.

Croll, J. 1868c. XLVII. On geological time, and the probable date of the glacial and the Upper Miocene period. The London, Edinburgh, and Dublin Philosophical Magazine and Journal of Science, Series $4 \mathbf{3 6}$, $362-86$.

Croll, J. 1869a. XXVI. On the physical cause of the motion of glaciers. The London, Edinburgh, and Dublin Philosophical Magazine and Journal of Science, Series 4 37, 201-06.

Croll, J. 1869b. V.-On the influence of the gulf-stream. Geological Magazine 6, 57-162.

Croll, J. 1869c. On Mr. Murphy's theory of the cause of the glacial climate. Geological Magazine 6, 382-83.

Croll, J. 1869d. XXVI. On the opinion that the southern hemisphere loses by radiation more heat than the northern, and the supposed influence that this has on climate. The London, Edinburgh, and Dublin Philosophical Magazine and Journal of Science, Series 4 38, 220-29.

Croll, J. 1870a. On two river channels (between Forth and Clyde) buried under drift belonging to a period when the land stood several hundred feet higher than at present. Transactions of the Edinburgh Geological Society 1, 330-45.

Croll, J. 1870b. XII. On ocean-currents. Part I. Ocean-currents in relation to the distribution of heat over the globe. The London, Edinburgh, and Dublin Philosophical Magazine and Journal of Science, Series 4 39, $81-106$. 
Croll, J. 1870c. XXIV. On ocean-currents. Part II. Ocean-currents in relation to the physical theory of secular changes of climate. The London, Edinburgh, and Dublin Philosophical Magazine and Journal of Science, Series 4 39, 180-94.

Croll, J. 1870d. V.- The boulder-clay of Caithness a product of land-ice. Part I. The nature of the Caithness Boulder-clay. Geological Magazine 7, 209-14.

Croll, J. 1870e. VI.- The boulder-clay of Caithness a product of land-ice. Part II. Geological Magazine 7, 271-78.

Croll, J. 1870f. XIX. On the cause of the motion of glaciers. The London, Edinburgh, and Dublin Philosophical Magazine and Journal of Science, Series 4 40, 153-70.

Croll, J. 1870g. XXIX. On ocean-currents. Part III. On the physical cause of ocean-currents. The London, Edinburgh, and Dublin, Philosophical Magazine and Journal of Science, Series 4 40, 233-59.

Croll, J. 1871a. XXIX. On ocean-currents. Part III [continued]. On the physical cause of ocean-currents. The London, Edinburgh, and Dublin, Philosophical Magazine and Journal of Science, Series 4 42, 241-80.

Croll, J. 1871b. IV. - On the transport of the Wastdale Crag blocks. Geological Magazine 8, 15-20.

Croll, J. 1871c. I.-On a method of determining the mean thickness of the sedimentary rocks of the globe. Geological Magazine 8, 97-102.

Croll, J. 1871d. Mean thickness of the sedimentary rocks. Geological Magazine 8, 285-87.

Croll, J. 1871e. On the Age of the Earth as determined from tidal retardation. Nature 4, 323-24.

Croll, J. 1872a. Ocean currents. Nature 5, 201-02.

Croll, J. 1872b. Ocean currents. Nature 5, 263.

Croll, J. 1872c. Ocean currents. Nature 5, 399.

Croll, J. 1872d. Ocean currents. Nature 5, 502-03.

Croll, J. 1872e. Ocean currents. Nature 6, 240-41.

Croll, J. 1872f. Kinetic energy. Nature 6, 324.

Croll, J. 1872g. Oceanic circulation. Nature 6, 453-54.

Croll, J. 1872h. I. What determines molecular motion? - The fundamental problem of nature. The London, Edinburgh, and Dublin Philosophical Magazine and Journal of Science, Series 4 44, 1-25.

Croll, J. 1874a. XIV. On ocean-currents. Part III. On the physical cause of ocean-currents. The London, Edinburgh, and Dublin, Philosophical Magazine and Journal of Science, Series 4 47, 94-122.

Croll, J. 1874b. XXIII. On ocean-currents. Part III. On the physical cause of ocean-currents. The London, Edinburgh, and Dublin, Philosophical Magazine and Journal of Science, Series 4 47, 168-90.

Croll, J. 1874c. Ocean currents. Nature 10, 52-53.

Croll, J. 1874d. V.-On the south of England ice-sheet. Geological Magazine $\mathbf{1}, 257$.

Croll, J. 1874e. III.- On the physical cause of the submergence and emergence of the land during the glacial epoch. Geological Magazine 1, 306-14, 1, 346-353.

Croll, J. 1875a. Climate and time in their geological relations: a theory of secular changes of the Earth's climate. London: Daldy, Isbister \& Co. [In the USA, this was published with the same pagination in New York by D. Appleton and Company; A reprint of the American edition was published in 1885 by Adam and Charles Black, Edinburgh.].

Croll, J. 1875b. Climate and time. Nature 12, 329.

Croll, J. 1875c. XXVI. The 'challenger's' crucial test of the wind and gravitation theories of oceanic circulation. The London, Edinburgh, and Dublin Philosophical Magazine and Journal of Science, Series 4 50, 242-50.

Croll, J. 1875d. XXXIV. The wind theory of oceanic circulation.-Objections examined. The London, Edinburgh, and Dublin, Philosophical Magazine and Journal of Science, Series 4 50, 286-90.

Croll, J. 1875e. LVII. Further remarks on the "crucial-test" argument. The London, Edinburgh, and Dublin Philosophical Magazine and Journal of Science, Series 4 50, 489-91.

Croll, J. 1875f. Oceanic circulation. Nature 12, 494.

Croll, J. 1875g. Oceanic circulation. Nature 13, 66-67.

Croll, J. 1876a. On the tidal retardation argument for the age of the Earth. British Association Report, 1876, Notices and abstracts of miscellaneous communications to the sections, 88-89.

Croll, J. 1876b. V.- Remarks on Mr. Burns's paper on the mechanics of glaciers. Geological Magazine 3, 361-64.

Croll, J. 1876c. XXXII. On the transformation of gravity. The London, Edinburgh, and Dublin Philosophical Magazine and Journal of Science, Series 5 2, 241-54.

Croll, J. 1877. On the probable origin and age of the sun. Quarterly Journal of Science 7, 307-26.

Croll, J. 1878a. VI. Le Sage's theory of gravitation. The London, Edinburgh, and Dublin, Philosophical Magazine and Journal of Science, Series 5 5, 45-46.

Croll, J. 1878b. The age of the sun in relation to evolution. Nature 17, 206-07.
Croll, J. 1878c. Age of the sun in relation to evolution: motion of the stars. Nature 17, 321

Croll, J. 1878d. Age of the sun in relation to evolution. Nature 17, 464-65.

Croll, J. 1878e. I. On the origin of nebulae. The London, Edinburgh, and Dublin, Philosophical Magazine and Journal of Science, Series 56 , $1-14$

Croll, J. 1878f. II. - Cataclysmic theories of geological climate. Geological Magazine 5, 390-98.

Croll, J. 1879a. Zöppritz on ocean currents. Nature 19, 202-04.

Croll, J. 1879b. Climatic effects of the present eccentricity. Nature 20, 602.

Croll, J. 1879c. The thickness of the Antarctic Ice, and its relations to that of the glacial epoch. Quarterly Journal of Science 9, 1-34.

Croll, J. 1879d. Summary material within the Geology article, Section II. The movements of the Earth in their geological relations. In Anon, The Encyclopadia Britannica. A dictionary of Arts. Sciences and general literature. $9^{\text {th }}$ edition, volume X, 218-220. Edinburgh: Adam \& Charles Black; and in Geikie, A. (1882) Text-book of geology, 23-29. London: Macmillan.

Croll, J. 1879e. Interglacial periods. Geological Magazine 6, 480

Croll, J. 1879f. Why the air at the equator is not hotter in January than in July. Nature 21, 129-30.

Croll, J. 1880a. III. - Mr. Hill on the cause of the glacial epoch. Geological Magazine 7, 66-7.

Croll, J. 1880b. The temperature of space and its bearings on terrestrial physics. Nature 21, 551-2.

Croll, J. 1880c. Aqueous vapour in relation to perpetual snow. Nature 22, 191-92.

Croll, J. 1883a. ART. II. - Evolution by force impossible: a new argument against materialism. The British Quarterly Review 77, 35-71.

Croll, J. 1883b. XXXVII. On some controverted points in geological climatology; a reply to Professor Newcomb, Mr. Hill, and others. The London, Edinburgh, and Dublin Philosophical Magazine and Journal of Science, Series 5 16, 241-64.

Croll, J. [presumed] 1883c. Postscript to Dr. Croll's paper on geological climatology. The London, Edinburgh, and Dublin Philosophical Magazine and Journal of Science, Series 5, 16, 320.

Croll, J. 1883d. XLIX. The ice of Greenland and the Antarctic continent not due to elevation of the land. The London, Edinburgh, and Dublin Philosophical Magazine and Journal of Science, Series 5 16, 351-60.

Croll, J. 1884a. XII. Examination of Mr. Alfred R. Wallace's modification of the physical theory of secular changes of climate. The London, Edinburgh, and Dublin Philosophical Magazine and Journal of Science, Series 5 17, 81-111.

Croll, J. 1884b. XXXII. Remarks on professor Newcomb's "Rejoinder". The London, Edinburgh, and Dublin Philosophical Magazine and Journal of Science, Series 5 17, 275-81.

Croll, J. 1884c. XLI. Examination of Mr. Alfred R. Wallace's modification of the physical theory of secular changes of climate. Part II, Geological and palæontological facts in relation to Mr. Wallace's modification of the theory. The London, Edinburgh, and Dublin Philosophical Magazine and Journal of Science, Series 5 17, 367-76.

Croll, J. 1884d. XXXIII. On the cause of mild polar climates. The London, Edinburgh, and Dublin Philosophical Magazine and Journal of Science, Series 5 18, 268-88.

Croll, J. 1885a. II. On Arctic interglacial periods. The London, Edinburgh, and Dublin Philosophical Magazine and Journal of Science, Series 5 19, 30-42.

Croll, J. 1885b. Discussions on climate and cosmology. London: Edward Stanford. [Also published by Adam and Charles Black, Edinburgh; in the USA it was published with the same pagination in New York by D. Appleton and Company.]

Croll, J. 1887 (published 1896). Autobiographical sketch of James Croll. In J. C. Irons Autobiographical sketch of James Croll LL.D., F.R.S. etc. with memoir of his life and work, 9-41, Prefatory note, 5. London: Edward Stanford.

Croll, J. 1889a. Rate of subaërial denudation. Geological Magazine 6, 526.

Croll, J. 1889 b. On prevailing misconceptions regarding the evidence which we ought to expect of former glacial periods. Quarterly Journal Geological Society 45, 220-26.

Croll, J. 1889c. Stellar evolution and its relations to geological time. London: Edward Stanford. [In the USA, this was published with the same pagination in New York by D. Appleton and Company.]

Croll, J. 1890a. Former glacial periods. Nature 41, 441.

Croll, J. 1890b. The philosophical basis of evolution. London: Edward Stanford.

\subsection{Published sources}

A. G. [=Archibald Geikie?] 1890. James Croll, F.R.S. Nature 43, 180-81. 
Alexander, J. 1900. Stories of self-help. Recent and living examples of men risen from the ranks. London: S.W. Partridge \& Co.

Ancestry. 2021. Ancestry. www.ancestry.co.uk (accessed July 2021).

Anon. [=George J. Romanes] 1883. The more excellent way. London: Macmillan.

Anon. 1890. James Croll, LL.D., F.R.S. Athencum 20 December 1890 3295,859 .

Anon. 1901. Obituary. James Bennie. Geological Magazine 8, 143-44.

Bailey, E. 1952. Geological survey of Great Britain. London: Thomas Murby \& Co.

Ball, R. 1891, The cause of an ice age. 1st edn. London: Kegan Paul, Trench, Trübner, \& Co

Berger, A. \& Andjelić, T. P. 1988. Milutin Milankovitch, père de la théorie astronomique des paléoclimats. Histoire \& Mesure 1 January 1988 385-402.

Betterton, J. 2019a. The Geikie Archive at Haslemere Educational Museum. In Betterton, J., Craig, J., Mendum, J. R., Neller, R. \& Tanner, J. (eds) Aspects of the life and works of Archibald Geikie, 223-54. London: Geological Society of London, Special Publication 480

Betterton, J. 2019b. Unpublished manuscripts of Archibald Geikie. In Betterton, J., Craig, J., Mendum, J. R., Neller, R. \& Tanner, J (eds) Aspects of the life and works of Archibald Geikie, 255-316. London: Geological Society of London, Special Publication 480

Betterton, J. 2019c. Archival resources. In Betterton, J., Craig, J., Mendum, J. R., Neller, R. \& Tanner, J. (eds) Aspects of the life and works of Archibald Geikie, 317-18. London: Geological Society of London, Special Publication 480.

Bol'shakov, V., Kapitsa, A. P. \& Rees, W. G. 2012. James Croll: a scientist ahead of his time. Polar Record 48, 201-05.

Bol'shakov, V. \& Kapitsa, A. 2010. James Croll - scientist, who left his time behind. Geography, Environment, Sustainability 3, 101-06.

Brassington, L. 2017. Corresponding conviction: the establishment of authority in the letters of James Croll. MPhil Dissertation, University of Cambridge.

Brassington, L. 2021a. Constructing science and status in Charles Darwin's cross-class correspondence network. $\mathrm{PhD}$ thesis, University of Cambridge.

Brassington, L. 2021b. The 'Janitor-geologist' and the 'cold materialistic scientific men': James Croll's navigation of scientific societies. Earth and Environmental Science Transactions of the Royal Society of Edinburgh 112, 211-222.

Bryson, B. 2004. A short history of nearly everything. London: Black Swan.

Burchfield, J. 2009. Lord Kelvin and the age of the Earth. Chicago: University of Chicago Press.

Burchfield, J. D. 1974. Darwin and the dilemma of geological time. Isis $65,301-21$

Carpenter, W. B. 1871. On the Gibraltar current, the gulf stream, and the general oceanic circulation. Proceedings of the Royal Geographical Society of London 15, 54-91.

Carpenter, W. B. 1874a. Ocean currents. Nature 9, 423-24.

Carpenter, W. B. 1874b. XLV. On the physical cause of ocean-currents. The London, Edinburgh, and Dublin Philosophical Magazine and Journal of Science 47, 359-62.

Carpenter, W. B. 1874c. Further inquiries on oceanic circulation. Proceedings of the Royal Geographical Society of London 18, 301-407.

Clarke, I. \& Mussell, J. 2015. Conservative attitudes to old-established organs: Oliver Lodge and Philosophical Magazine. Notes and Records of the Royal Society 69, 321-36.

Culverwell, E. P. 1896. The astronomical theory of the ice age. Nature 53, 269.

Darwin, C. 1869. On the origin of species by means of natural selection, or the preservation of favoured races in the struggle for life. 5th edn. London: John Murray.

Darwin, G. H. 1896. The astronomical theory of the glacial period. Nature 53, 196-97.

Davis, W. M. 1894. Note on Croll's glacial theory. Transactions of the Edinburgh Geological Society 7, 77-80.

Deacon, M. 1971. Scientists and the sea 1650-1900. A study of marine science. London \& New York: Academic Press.

Dry, S. 2019. Waters of the world: the story of the scientists who unravelled the mysteries of our seas, glaciers, and atmosphere - and made the planet whole. London: Scribe.

Dryerre, H. 1903. Blairgowrie, Stormont and Strathmore worthies. Blairgowrie: Henry Dryerre; Paisley: Alexander Gardner; Edinburgh: John Menzies.

Edwards, K. J. 2021. James Croll and 1876 - an exceptional year for a 'singularly modest man'. Earth and Environmental Science Transactions of the Royal Society of Edinburgh 112, 193-209.

Edwards, K. J. \& Robinson, M. 2021. James Croll - a man 'greater far than his work'. Earth and Environmental Science Transactions of the Royal Society of Edinburgh 112, 173-192.
Everett, J. D. 1872. Ocean currents. Nature 5, 243.

F. R. S. 1874. Ocean circulation - Dr. Carpenter and Mr. Croll. Nature 10, 83-84.

Fairbridge, R. W. 1961. Convergence of evidence on climatic change and ice ages. Annals of the New York Academy of Sciences 95, 542-79.

FamilySearch. 2021. FamilySearch. www.familysearch.org (accessed July 2021).

Farrow, G. E. 2001. James Croll: a 19th Century pioneer of climate change. Glasgow Naturalist 23, 9-18.

Ferguson, K. 2017. Lost science: astonishing tales of forgotten genius. New York: Sterling.

Fichman, M. 1977. Wallace: zoogeography and the problem of land bridges. Journal of the History of Biology 10, 45-63.

Find a Grave. 2021. James Croll. https://www.findagrave.com/memorial/ 150953145/james-croll (accessed April 2021)

Finnegan, D. A. 2012. James Croll, metaphysical geologist. Notes and Records of the Royal Society 66, 69-88.

Fisher, O. 1866. II.- On the probable glacial origin of certain phenomena of denudation. Geological Magazine 3, 483-87.

Fleming, J. R. 2006. James Croll in context: the encounter between climate dynamics and geology in the second half of the nineteenth century. History of Meteorology 3, 43-53.

Gamble, C. 2021. Making deep history: zeal, perseverance, and the time revolution of 1859. Oxford: Oxford University Press.

Geikie, J. 1874. The great Ice Age and its relation to the antiquity of man. 1st edn. London: W. Isbister \& Co.

Gribbin, J. R. \& Gribbin, M. 2001. Ice age. London: Allan Lane.

Hamlin, C. 1982. James Geikie, James Croll, and the eventful ice age. Annals of Science 39, 565-83.

Hilgen, F. J. 2010. Astronomical dating in the 19th century. Earth-Science Reviews 98, 65-80

Horne, J. 1892. Obituary notice of Dr. James Croll, F.R.S. Transactions of the Edinburgh Geological Society 6, 171-87.

Howorth, H. H. 1892. Sir R. Ball's "Cause of an Ice Age". Nature 45, 440

Imbrie, J., Hays, J. D., Martinson, D. G., McIntyre, A., Mix, A. C. Morley, J. J., Pisias, N. G., Prell, W. L. \& Shackleton, N. J. 1984 The orbital theory of Pleistocene climate: support from a revised chronology of the marine $\delta 18 \mathrm{O}$ record. In Berger, A. L., Imbrie, J., Hays, J., Kukla, G. \& Saltzman, B. (eds) Milankovitch and climate: understanding the response to astronomical forcing, 269-305. Dordrecht: D. Reidel.

Imbrie, J. \& Imbrie, J. Z. 1980. Modeling the climatic response to orbital variations. Science 207, 943-53.

Imbrie, J. \& Imbrie, K. P. 1979. Ice ages: solving the mystery. London: Macmillan

Irons, J. C. 1896. Autobiographical sketch of James Croll LL.D., F.R.S. etc. with memoir of his life and work. London: Edward Stanford.

J. G. [=James Geikie] 1890. Obituary: 1890. Croll, James, LL.D., F.R.S. Scottish Geographical Magazine 7, 89-90.

Kang, S. M., Seager, R., Frierson, D. M. \& Liu, X. 2015. Croll revisited: why is the northern hemisphere warmer than the southern hemisphere? Climate Dynamics 44, 1457-72.

Kneale, A. 2019. Remarkable Scottish scientist James Croll who developed revolutionary theory of climate change. https://www.transceltic.com/blog/remarkable-scottish-scientist-james-croll-who-developed-revolutionary-theory-of-climate-change (accessed June 2019).

Kushner, D. 2004. Croll, James (1821-1890), Oxford Dictionary of National Biography. https://doi.org/10.1093/ref:odnb/6744 (accessed June 2021).

Lyell, C. 1867. Principles of geology or the modern changes of the earth and its inhabitants considered as illustrative of geology. 10th edn, volume 1. London: John Murray.

Micklethwait, B. 2004. James Croll and the ages of ice. http://www.brianmicklethwait.com/education/archives/001380.htm (accessed June 2021).

Mills, E. 2009. The fluid envelope of our planet: how the study of ocean currents became a science. Toronto: University of Toronto Press.

Mivart, S. G. 1889. On truth: a systematic enquiry. London: Kegan Paul, Trench \& $\mathrm{Co}$

Muller, R. A. \& MacDonald, G. J. 1997. Glacial cycles and astronomical forcing. Science 277, 215-18

Newcomb, S. 1876. Art. XXXII. -Review of Croll's climate and time with especial reference to the physical theories of climate maintained therein. American Journal of Science and Arts Series 3 11, 263-73.

Pearce, F. 2018. Caretaker who solved the ice age mystery. New Scientist 239, 34-35.

Petrović, A. \& Marković, S. B. 2010. Annus mirabilis and the end of the geocentric causality: why celebrate the 130th anniversary of Milutin Milankovic? Quaternary International 214, 114-18.

Raymo, M. E. \& Huybers, P. 2008. Unlocking the mysteries of the ice ages. Nature 451, 284-85.

RLF. 2021. Royal Literary Fund. https://www.rlf.org.uk/home/aboutthe-rlf/ (accessed February 2021) 
Robinson, M. 2020. Inspiring people at home: Mike Robinson RSGS CEO. https://www.youtube.com/watch?time_continue $=10 \& \mathrm{v}=$ FKF8novHwiU\&feature=emb_logo (accessed June 2021).

Romano, M., Rubidge, B. \& Sardella, R. 2021. A century since the recognition of cyclic climatic change by Milanković. Rendiconti Online della Società Geologica Italiana 53, 9-13.

Rothschild, R. E. 2008. The light of genius: James Croll's theory on climate. BA Senior Thesis (History), Princeton University.

Seibold, E. \& Berger, W. 1982. The sea floor: an introduction to marine geology. Berlin: Springer-Verlag.

Sexton, A. H. 1894. The first technical college: a sketch of the history of 'The Andersonian', and the institutions descended from it, 17961894. London: Chapman and Hall.

Smith, C. 2021. The Alfred Russel Wallace page. https://people.wku.edu/ charles.smith/wallace/S531A.htm (accessed July 2021).

Somervail, A. 1877. On the glacial phenomena of Scotland, with special reference to the recent works of Dr. Croll and Mr. James Geikie. Transactions of the Edinburgh Geological Society 3, 88-97.

Sotheby, Wilkinson \& Hodge. 1924. Catalogue of valuable printed books, autograph letters and historical documents, 10 April 1924, 29. London: Sotheby, Wilkinson \& Hodge.

Sugden, D. E. 2014. James Croll (1821-1890): ice, ice ages and the Antarctic connection. Antarctic Science 26, 604-13.

Tasch, P. 1986. James Croll and Charles Lyell as glacial epoch theorists. Earth Sciences History 5, 131-33.

Thompson, R. 2015. Roy Thompson on James Croll. https://www.youtube.com/watch?v=vmTcSFglWaM (accessed June 2021).

Thomson, C. T. W. 1876. I. Report to the hydrographer of the admiralty on the cruise of HMS 'Challenger' from June to August 1875. Proceedings of the Royal Society of London 24, 32-40.
Thomson, W. 1891. November 30, 1891. Anniversary meeting. Proceedings of the Royal Society of London 50, 218-46.

Turton, J. 2021. John Turton. https://www.antiqbook.com/bookdealer. phtml?o=johnturton (accessed July 2021)

Tyndall, J. 1874. Address delivered before the British association assembled at Belfast with additions. London: Longmans, Green, \& Co.

University of Cambridge. 2021. Darwin Correspondence Project. https:// www.darwinproject.ac.uk/ (accessed April 2021)

Wallace, A. R. 1870. The measurement of geological time. Nature 1, $399-401$.

Wallace, A. R. 1880. Island life: or, the phenomena and causes of insular faunas and floras. London: Macmillan.

Wallace, A. R. 1896. The astronomical theory of a glacial period. Nature 53, 317.

Watt, J. 1890. Theories of the Ice Age and notes on the glacial geology of the immediate neighbourhood. The Transactions and Journal of the Proceedings of the Dumfriesshire \& Galloway Natural History \& Antiquarian Society, Series II 6, 85-88.

Woodward, H. B. 1873. Notes on the geology of the neighbourhood of wells, somerset. Somersetshire Archaeological and Natural History Society's Proceedings 19, 1-16.

Woolf, J. 2021. Popularising Croll: an opportunity for expression and creativity. Earth and Environmental Science Transactions of The Royal Society of Edinburgh 112, 309-312.

Woolf, J. \& Gibson, D. 2021. James Croll and his adventures in climate and time. Perth: Madwolf Design on behalf of Royal Scottish Geographical Society.

Zuidema, H. P. 1947. Discovery of letters by Lyell and Darwin. The Journal of Geology 55, 439-45.

MS received 10 July 2021. Accepted for publication 16 September 2021 